\title{
DİJITAL ÇAĞIN BİR PAZARLAMA VE MARKA İLETİŞİM ARACI OLARAK ETKİLEYICILER: KANAATLER, KRİTERLER VE TAKİP NEDENLERİ ÜZERİNE BİR ARAŞTIRMA
}

\author{
Ümit Arklan* - Nilgün Tuzcu**
}

\section{ÖZET}

Toplumsal yaşam içerisinde etkileşim halindeki bireyler, birbirlerinin kanaatlerini istemli/istemsiz yönlendirmekte, karar süreçleri üzerinde etkili olmaktadır. Dijitalleşme ve yeni iletişim teknolojilerinin ortaya çıkmasıyla kişilerin etkileşimi için eşzamanlılık ve mekânsal birliktelik şartı ortadan kalmış, küresel köyün herhangi bir köşesinde yer alan çok çeşitli nitelikteki insanlar tarafından farklı zaman dilimlerinde oluşturulan içerikler ilgili bireylerin tutum ve kanaatleri üzerinde belirleyici rol oynayarak davranışlarına yön verir duruma gelmiştir. Dijital dünyanın söz konusu imkanının farkında olan kurumsal yapılar diğer birçok etkinliği gibi pazarlama ve marka iletişimi faaliyetlerini de dijital ortama aktarmışlardır. Kurumsal yapılar, kurumsal imaj ve itibar yönetiminden satışları artırmaya dönük dijital pazarlama faaliyetlerine varıncaya dek çok sayıda amacı gerçekleştirmek üzere hedef kitle algısını yönetmeye dönük etkileyicilerden faydalanmaya başlamışlardır. Buradan hareketle çalışmada, etkileyicilere dijital çağın bir pazarlama ve marka iletişim aracı olarak odaklanılmakta, bu kişilere ilişkin genel kanaatleri, aranılan kriterleri ve takip edilme nedenlerini ortaya koyma amacı taşınmaktadır. Süleyman Demirel Üniversitesi öğrencileri üzerinde gerçekleştirilen alan araştırmasından elde edilen bulgular doğrultusunda, etkileyicilerde aranan kriterlerin, tarza, fiziki görünüşe ve yetkinliğe ilişkin kriterler olmak üzere üç boyutta değerlendirilebileceği; takip edilme nedenlerinin ise, bilgi edinme, hoşça vakit geçirme, bireysel tatmin ve etkileşim temelli nedenler

\footnotetext{
* Prof. Dr., Süleyman Demirel Üniversitesi İletişim Fakültesi ORCID ID: 0000-0003-0066-3122

** Doktora Öğrencisi, Süleyman Demirel Üniversitesi Sosyal Bilimler Enstitüsü ORCID ID: 00000002-2815-0559

Makale Gönderim Tarihi: 12.03.2019 - Makale Kabul Tarihi: 26.04.2019
} 
şeklinde kategorize edilebileceği, sosyo-demografik özellikler bağlamında yapılan karşılaştırmalarla birlikte ortaya konulmaktadır.

Anahtar Kelimeler: Etkileyiciler, Etkileyici Kişi Pazarlaması, Dijital Pazarlama, Marka İletişimi, Sosyal Medya.

\title{
INFLUENCERS AS A TOOL OF MARKETING AND BRAND
}

\section{COMMUNICATION OF THE DIGITAL AGE: STUDY ON JUDGEMENTS, CRITERIAS AND FOLLOW-UP REASONS}

\begin{abstract}
Individuals interacting in social life are guiding each other's opinions voluntarily or involuntarily and are mutually influential in each other's decision process. With the emergence of digitalization and new communication technologies, the necessity of concurrency and spatial unity for the interaction of individuals has disappeared. The contents created in different periods of time by people who have various qualities located in any corner of the global village have been determining the behaviors of individuals with their attitudes and opinions. The corporate structures, which are aware of the possibility of the digital world, have also digitized marketing and brand communication activities, such as many other activities. They started to take advantage of influencers in order to manage the target audience's perception in order to achieve a number of goals from image and reputation management to digital marketing activities aimed at increasing sales. The aim of this study is to focus on the influencers as a marketing and brand communication tool of the digital age and to put forward the general convictions, the requested criteria and the reasons for following. According to the findings obtained from the field research conducted on the students of Suleyman Demirel University, the criteria that requested in influencers can be evaluated in three dimensions: criteria for style, physical appearance and competence; the reasons for being followed can be categorized as reasons for acquiring information, having a
\end{abstract}


pleasant time, individual satisfaction and interaction and these criterias are presented as a context of socio-demographic characteristics.

Keywords: Influencers, Influencer Marketing, Digital Marketing, Brand Communication, Social Media.

\section{GíRiş}

Bilgi iletişim teknolojilerinde vuku bulan gelişmeler neticesinde birçok alanda dönüşümler yaşanmış, buna bağlı olarak değişen tüketici davranışlarının etkisiyle pazarlama ve marka iletişimi alanında da farklı yöntemlerin denenmesi zorunlu hale gelmiştir. Bu yöntemlerden biri olan etkileyici kişi pazarlaması; dijitalleşme ve yeni iletişim kanallarının ortaya çıkması ile kurumların hedef kitlelerine ulaşmak, sıcak ve samimi ilişkiler geliştirerek hedef kitle algısını ve markanın imaj ve itibarını yönetmek, aynı zamanda dijital pazarlama stratejilerini etkili bir şekilde kullanarak satışlarını artırmak amacıyla başvurdukları bir alan olarak kendine yer bulmuştur.

Dijital dünyayla gelen bu yeni dönem pazarlama yöntemi, etkileyici olarak isimlendirilen kişiler tarafından Youtube, Twitter, Instagram gibi sosyal medya platformlarında oluşturulan içerikler temelinde hayat bulmakta, 'etki gücü yüksek bu kişilerin herhangi bir marka, ürün veya hizmetle ilgili takipçi kitlesinin düşüncelerini değiştirmeye, davranışlarını etkilemeye ve söz konusu davranışları satışa dönüştürmeye yönelik olarak düzenlenen tanıtım veya reklam çalışmalarına dayanmaktadır' (Coşkun 2018: 1). Etkileyici kişi pazarlamasında aracı olma rolü üstlenen ve sosyal medya ortamlarında takipçi sayısı ve buna bağlı olarak etkileme gücü yüksek popüler kişiler olarak değerlendirilen etkileyiciler, hedef kitle ile doğrudan temas kurulması, informal bir süreç içerisinde bilgi akışının sağlanması, uzun soluklu samimi ilişkilerin tesisi ve etkileşimsel birlikteliklerin temini noktasında kurumsal yapılara büyük yarar potansiyelleri taşımaktadır. Bu bağlamda, kurumlar, sahip oldukları hedef kitle profiline uygun ve kendilerini en 
iyi şekilde temsil edeceklerini düşündükleri etkileyiciler ile çalışmalarını sürdürmeye gayret etmekte, bu noktada da 'kimi zaman çeşitli ajanslardan yardım almaktadırlar' (Gerçek Gündem 2018).

Yukarıdaki bilgiler ışığında çalışma; dijital pazarlama ve marka iletişim aracı olarak etkileyicilere ilişkin genel kanaatleri, aranılan kriterleri ve takip edilme nedenlerini ortaya koyma amacı taşımaktadır. Bu doğrultuda, öncelikle konu minvalinde bir literatür taraması yapılarak, dijital çağda pazarlama ve marka iletişimi, yeni iletişim ortamlarında etkileyiciler ve etkileyici kişi pazarlaması ve etkileyicilerin tüketiciler/takipçiler üzerindeki etki potansiyelleri üzerinde durulmakta; ardından daha önce ulusal ve uluslararası literatüre kazandırılmış çalışmalar, ilgili çalışmalar başlığı altında betimlenmektedir. Son kısımda ise, çalışmanın ana çatısını oluşturan, alan araştırmasından elde edilen bulgular birbirleriyle ilişkilendirilerek ve karşılaştırmalı analizlere tabi tutularak değerlendirilmekte, ulaşılan sonuçlar tartışılmaktadır.

\section{Literatür Taraması}

\subsection{Dijital Çağda Pazarlama ve Marka İletişimi}

Dijital çağın kendine özgü karakteristik özellikleri ve getirileriyle birlikte, pazarlama ve marka iletişiminde son y1llarda belirgin nitelikte değişimler gözlemlenir olmuştur. Dijitalleşme ve dijital teknolojiler, söz konusu alanlarda kurumsal yapılara belirli noktalarda kolaylıklar sağlarken, belirli konularda ise çok daha komplike düşünce tarzını benimseyerek ayrıntıcı bakış açısıyla hareket etmelerini ve titiz davranmalarını zorunlu kılmıştır. Rakiplerinden ayrışarak kendisini hedef kitlesi gözünde farklı bir yere konumlandırma gayreti içerisinde olan kurumlar ve markalar, 'pazar ortamında geçmişe göre daha fazla rakiplerin olmasının yanı sıra, birden çok medya fırsatının ortaya çıkması, günümüz tüketicilerinin daha akıllı, bilgili, araştıran ve seçici kişiler haline dönüşmesi' (Erdil ve Uzun 2009: 162) gibi sebeplerle, pazarlama ve tanıtım faaliyetlerini de içeren tüm iletişimsel aktivitelerine çok boyutlu bir yaklaşım sergilemek, dijital ortamları ve onların getirilerini hesaba katarak yön vermek durumunda kalmışlardır. 
Esasında, geçmişte olduğu gibi bugün de bir markanın tüketicilerin duygularına önem vermesi, problemlerine çözüm üretmesi, farklı kanallar aracılığı ile çift yönlü iletişim sağlayarak onlara sosyal ve psikolojik faydalar sunması ve bunların sonucunda satış planının gerçekleşmesi marka iletişiminin dayanak noktasını oluşturmaktadır (Kotler ve Pfoertsch 2010: 133-134). Ancak, eskiden pek çok iletişim platformu bir araya getirilerek hedef kitle üzerinde büyük bir etki yaratılmaya çalış1lırken (Erdil ve Uzun 2009: 162-163) son y1llarda dijitalleşme fırtınası ile tüketicilerin internet kullanımının ve bunun içerisinde 'paylaşım ve iletişim sınırı olmaksızın özgür ve özgün bilgi aktarımı' (Özutku ve ark. 2014: 8182) ve eğlence ortamı sağlayan sosyal medya mecralarında geçirilen sürenin artması, markaların hedef kitleye ulaşma yönündeki stratejilerini değiştirmiştir (Ayhan 2012: 79). Artık markalar, konvansiyonel iletişim araçlarından yeni iletişim teknolojilerine varıncaya kadar, oldukça geniş bir yelpazede hedef kitle eğilimlerini tespit ederek, mevcut kaynaklar doğrultusunda iyi bir medya planlaması yapmak, dağıtım kanallarından pazarlama süreçlerine hatta insan kaynaklarına dek birçok yapısal ve işlevsel dönüşümü gerçekleştirerek dijitalleşmeye ayak uydurmak durumundadır.

Dijitalleşmeye ayak uyduran kurumsal yapılar, dijital dağıtım kanallarını kullanarak marka ile tüketici arasında interaktif iletişim kuran bunun neticesinde tüketicilerin mal ve hizmet satın almalarını sağlayan dijital pazarlama sayesinde (Varnalı 2013: 59), tüketicilerin mağazaya gitmelerine gerek kalmadan internet üzerinden birçok ürün çeşitliliğine ulaşabilmesini, herhangi bir ürün hakkında bilgi alabilmesini ve bir ürünü veya markayı kullanan diğer kullanıcılarla etkileşim halinde olabilmesini temin etmektedir (McAlexander ve ark. 2002: 43). Günümüz tüketicileri artık kendileri gibi birilerine güvenmeyi yeğlemekte, blogger tavsiyelerini önemsemekte, forumları okumakta, sosyal ağlarda görüş alışverişinde bulunmakta olduğundan (Ayhan 2012: 79), sosyal ağ platformlarında mesajların ağızdan ağıza yayılma imkânı markalara ve tüketicilere interaktif iletişim ve etkileşim üstünlüğü sağlamaktadır (Zhang ve ark. 2013: 1). Bu sayede 
hem tüketiciler sosyal ağ platformlarında diğer kullanıcılar tarafından bir markaya ilişkin paylaşılan beğeni ve yorumlar sayesinde ihtiyaç duydukları herhangi bir bilgiye kısa sürede ulaşmakta hem de markalar tüketiciler tarafından dönen geri bildirimler neticesinde daha sağlam ve farklı reklam taktikleri uygulayabilmektedir (Koçyiğit 2015: 102). Önceleri marka ile tüketici arasındaki iletişimi güçlendirmek adına reklamlarında daha çok ünlü kişilerden faydalanan markalar, bugün sosyal medya ortamlarında bir tür ünlü kullanımına karşılık gelen etkileyiciler ile iş birliği yapmakta (Sammis ve ark. 2015: 8), her kuşağın farklı düzeylerde deneyimlediği dijital ortamda (Arklan ve Kartal, 2018: 956) bir nevi kanaat önderi rolü oynayan bu kişiler sayesinde, kendilerinin temsil edilmesi, hedef kitleler üzerinde istenen etkinin bırakılması yönünde gayret göstermektedir.

\subsection{Yeni İletişim Ortamlarında Etkileyiciler ve Etkileyici Kişi Pazarlaması}

Etkileyici (influencer) sözcüğü, English Oxford Living Dictionaries sözlüğünde (2019) genel kullanımda "başka birini etkileyen bir kişi ya da şey" olarak, pazarlama açısından kullanımda, “öğeleri sosyal medyada terfi ettirerek veya önererek potansiyel ürün veya hizmet alıcılarını etkileme becerisi olan bir kişi" olarak tanımlanırken; Cambridge Dictionary sözlüğünde (2019) ise genel kullanımda "başkalarının davranış şeklini etkileyen veya değiştiren biri" biçiminde, pazarlama açısından kullanımda, "başkalarının davranışlarını veya görüşlerini etkileyebilecek bir kişi veya grup" şeklinde tanımlanmakta, her iki sözlükte de etkileyici kişi pazarlaması (influencer marketing) sözcügüune ilişkin herhangi bir karşılığa rastlanamamaktadır.

Influencer ve influencer marketing kavramlarının Türkçe karşılıklarına dair ilgili literatüre bakıldığında, bir fikir birliğinin sağlandığını söylemek güçtür. Influencer kelimesi için "etkileyen, nüfuzlu, hatırlı, sözü geçen, yön veren, fenomen, mikro ünlü, fikir lideri, kanaat önderi” gibi kavramsallaştırmalar söz konusuyken (Mert 2018, Maden 2018, Tahtalı 2018, Yaman 2018, Yaylagül 2017, Avcılar ve ark. 2018, Aslan ve Ünlü 2016, Sabuncuoğlu ve Gülay 2014, Uyar 2014, Akdevelioğlu 2013), influencer marketing kavramı için “hatırlı pazarlama, 
etkileyici kişi pazarlaması, etkileyici pazarlama, fenomen pazarlama, nüfuz pazarlaması" gibi kullanımlarla karşılaşmak mümkündür (Öztürk ve Şener 2018, Alikılıç ve Özkan 2018, Aktaş 2018, Coşkun 2018, Kolcuoğlu 2018, Özbek 2018, Görgülü ve Farajova 2017). Bu çalışmada, ilgili kavramların literatürde kullanımlarına dair yapılan inceleme ve değerlendirmelerin ardından, influencer kavramı için etkileyici, influencer marketing kavramı için de etkileyici kişi pazarlaması ifadelerinin kullanılmasının uygun olduğuna karar verilmiştir.

Etkileyici kişi pazarlaması, verdikleri tavsiyelerle potansiyel müşterilerin kuşkularını gidererek onların kararları üzerinde etkili olan bireyler aracılığıyla faaliyetlerini hayata geçiren yeni bir pazarlama yaklaşımıdır (Brown ve Hayes 2008: xi). Sunulmak istenen ürünü hedeflenen tüketiciye ulaştırmada en etkili yollardan birisi olup (Lincoln 2016), Twitter, Facebook, Pinterest, Instagram gibi sosyal medya platformlarında kurumların marka farkındalığı yaratmasında ve takipçi sayılarının artmasında katkı sağlamaktadır (Sammis ve ark. 2015: 21). Bu pazarlama türünün temel dayanağı konumunda olan etkileyiciler ise, çevrimiçi sosyal ağlarda günlük hayatlarından edindikleri bilgileri ve görüntüleri paylaşarak sadık takipçiler geliştiren, diğer bireyleri (takipçilerini) yeni ürünler hakkında bilgilendiren, tavsiye veren, takipçilerin aldıkları kararları desteklemek veya teyit etmek için olumlu geri bildirimler sunan, takipçilerinin satın alacakları yeni ürüne ilişkin riski azaltan kısacası bilgilendirici, ikna edici, doğrulayıcı kişilerdir (Shimp 2007: 181). Takipçileri gözünde sahip oldukları konum itibariyle alınacak kararlarda ve atılacak adımlarda belirleyici bir rol üstlenip, tutum ve kanaatleri rahatlıkla yönlendirebildiklerinden kurumsal yapılar için oldukça önemli figürlerdir.

Sosyal medyayı aktif şekilde kullanan bu bireyler, sosyal medya platformlarında paylaşımları, yaptıkları yorumları, takipçi sayıları sayesinde "internet fenomeni" haline gelebilmekte ve diğer sosyal medya kullanıcılarını etkileyebilmektedir (Deneçli 2015: 87). Etkileyiciler her zaman milyonlarca sayıda takipçisi olan internet ünlüleri olmak zorunda değildir. Youtube, Instagram, Facebook, 
Snapchat, Twitter, vb sosyal ağlarda hesabı olan ve az sayıda da olsa belirli bir grubun kanaatini değiştirme gücüne sahip herkes etkileyici kişiler olarak kabul edilmektedir (Çelikkaya 2017). Bu bakımdan markalar için sosyal medya ortamlarında etkileyicilerle gerçekleştirilen reklamların önemi oldukça açıktır (Bóveda-Lambie ve Hair 2012). Bugün birçok kurum hedef kitlesi ile arasındaki bağı perçinlemek için etkileyicilerle belirli bir ücret karşılığı anlaşıp markalarının reklam yüzü olmaları veya reklamlarını yapmaları için etkileyici kişi pazarlamasından yararlanabilmektedir.

\subsection{Etkileyicilerin Tüketiciler/Takipçiler Üzerindeki Etki Potansiyelleri}

Pazarlama alanında gerçekleştirilen çalışmaları etkileyen en önemli faktörlerden birisi, insan psikolojisidir. Bütün reklam ve tanıtım faaliyetlerinde temel amaç tüketici ve ürün arasında kurulması istenen bağın psikolojik temellere dayandırılması ve tüketicinin ikna edilebilmesidir (Bayraktar 2017: 60-61). Bu yapılabildiği müddetçe arzulanan türden bir başarıdan söz etmek mümkündür.

Etkileyici kişi pazarlamasında bunu yapacak olanlar, kaynak konumunda bulunan kişiler yani etkileyicilerdir.

Karar verme süreçlerinde tüketiciler açısından birer yönlendirme ve motivasyon aracı olarak işlev gören bu kişiler, tüketicilerin bireysel özelliklerini, içerisinde yoğruldukları toplumsal dokuyu ve yaşanmışlıklarını göz önünde bulundurarak bu psikolojik süreçleri yönetmekte, onları nihai amaç olan satın alma davranışına yönlendirebilmektedir. İkna temeline dayalı gerçekleştirilen iletişimsel bir süreç olan bu pazarlama faaliyetinde, etkileyicinin hedef kitledeki alg1sı temel belirleyiciler arasında yer almaktadır. Söz konusu algı üzerinde ise, etkileyicilerin fiziksel niteliklerinden, uzmanlık alanlarına hatta sahip olduğu sosyo-kültürel özelliklere kadar birçok unsur birlikte rol oynamakta, tüketiciler/takipçiler tüm bu yönleriyle 'kendilerine benzer olduğunu düşündükleri kişilerin mesajlarından daha fazla etkilenmektedir' (Kim ve Jeong 2016: 1251).

İlgilendikleri konu hakkında geniş bir bilgi birikimine sahip, yeniliklere açık, sosyal ve kültürlü bireyler olma niteliğiyle fikir liderliği rolü üstlenen (Uyar 2014: 
77), sadece tüketicilerin kanaatlerini yönlendirmekle kalmayıp onlarla görüş alışverişinde bulunarak kendi söylem ve eylemlerine de yön veren, aynı zamanda takipçileri konumundaki bu bireylerin eğlenmelerini, rahatlamalarını, iyi vakit geçirmelerini sağlayan etkileyiciler, çoğunlukla tüketiciler tarafından birer motivasyon aracı olarak değerlendirilmektedir. 'Marka ile etkileyicinin şöhreti arasındaki uyum ve bu kişilerin beğenilme düzeyi ise, tüketicilerin reklama olan eğilimini, marka inançlarını ve satın alma niyetini etkilemekte' (Fleck ve ark. 2012: 651), marka ile uyumlu, deneyimli, bilgili, yetenekli etkileyiciler tarafından tanıtım ve reklamların yapılması, marka değerini yükseltici, satışları artırıcı, müşteri sadakatini perçinleyici türden olumlu katkı potansiyelleri taşımaktadır.

Etkileyicilerin vereceği doğru bilgileri içeren mesajlar tüketiciler/takipçiler açısından reklamın değerini artırırken, aldatıcı nitelik taşıyan mesajlar azaltıcı yönde bir etki yapmaktadır (Ducoffe 1995: 3). Mizah içerikli mesajlar, ilgili ürünün ve markanın bu tür bir mesaj örüntüsüne uygun olması ve dozunda kullanılması kaydıyla, tüketicileri/takipçileri gündelik yaşamın stresinden kurtarması ve onlarda bir sempati uyandırması yönüyle katkı sağlamaktadır. Etkileşimi esas alan mesajlar ise, ürün ve marka ile tüketiciler/takipçiler arasında bir bağ geliştirme gayesi taşımakta, uzun soluklu ve olabildiğince sorunsuz işleyen ilişkiler tesis etmeye çalışmaktadır. Etkileyicilerin bu durumun bilincinde hareket ederek, iletişimsel süreçlerini, markanın ve tüketicilerin/takipçilerin durumuna göre bilgilendirici olmakla birlikte, eğlendirici öğelere de yer verecek, kendisi ile hedef kitle konumundaki bireyler arasında etkileşim imkanı sağlayacak ve onların iletilen mesajları içselleştirebilmelerine ve kişiselleştirebilmelerine olanak tanıyacak şekilde kurgulamaya özen göstermeleri etki potansiyellerini üst noktalara taşıyacaktır.

\section{4. İlgili Çalışmalar}

Köklü nitelikte bir geçmişe sahip pazarlama literatürüne dijitalleşme ile girmiş kavramlar olan etkileyiciler ve etkileyici kişi pazarlaması, gerek ulusal gerekse uluslararası literatürde son dönemlerde üzerinde durulmaya başlanan kavramlar 
olma özelliği taşımaktadır. Bilgi ve iletişim teknolojilerinde yaşanan devrimsel nitelikli değişim ve gelişmelere koşut olarak önce uluslararası alanda sosyal bilimlerin konuya olan ilgisinin artması, ardından ulusal literatürün konu üzerine odaklanmaya başlaması, ilgili alanda ortaya konulan eser sayısını ve çeşitliliğini artırmıştır. Bunun neticesinde etkileyiciler ve etkileyici kişi pazarlamasına farklı yönlerden ve kendine özgü amaçlarla odaklanan kitap, makale ve tez gibi eserler vücut bulmaya başlamıştır.

$\mathrm{Bu}$ doğrultuda ilk olarak konuya odaklanan kitaplara bakılacak olursa, uluslararası literatürde; "Influencer: Building Your Personal Brand in the Age of Social Media" (Hennessy 2018) isimli, sosyal medyada nasıl takipçi elde edileceği, tüketicilerin bir markayı veya siteyi nasıl fark edebileceği hakkında bilgi veren çalışma, "Influencer Marketing for Dummies" (Sammis ve ark. 2015) adll, Facebook, Instagram, Blog, Twitter, Pinterest gibi sosyal medya ortamlarında bulunan etkileyicilerin işlevlerini konu alan çalışma, "Influencer Marketing: Who Really Influences Your Customers?" (Brown ve Hayes 2008) ismini taşıyan ve ağızdan ağıza pazarlamanın internet ortamındaki önemi ve etkileyici kişi pazarlamasının geleceği hakkında bilgiler ortaya koyan çalışma akla ilk gelenlerdir. Öte yandan ulusal literatürde konunun yeni keşfedilmesinden dolayı, “Dijital Çağın Mesleği: Nasıl Influencer Olunur?” (Bor ve Erten 2019) isimli, sosyal medya ortamlarının işleyişi doğrultusunda dijital çağın mesleklerine ve bu bağlamda da etkileyicilere odaklanan sadece bir çalışma göze çarpmaktadır. Bu çalışma dişında henüz kitap türünde başka herhangi bir esere rastlanamamakla birlikte, gerek uluslararası gerekse ulusal literatürde dijital pazarlama ve sosyal medya pazarlaması üzerine yazılmış çeşitli eserlerde de etkileyiciler ve etkileyici kişi pazarlaması hakkında bilgiler verilmekte ve ilgili kavramlar çeşitli bağlamlarda değerlendirilmektedir.

Konuya ilişkin uluslararası ve ulusal nitelik taşıyan çeşitli dergilerde yayımlanmış makaleler incelendiğinde; uluslararası literatürün daha zengin ve çeşitli olduğu, ulusal literatürde ise ilgili alana yeni yeni yönelimlerin başladığı dikkat 
çekmektedir. Uluslararası literatürde; sosyal medya ortamlarında etkileyiciler ve tüketiciler üzerindeki etkisi (Chatzigeorgiou 2017, De Veirman ve ark. 2017, Evans ve ark. 2017, Zhang ve ark. 2013, Kiss ve Bichler 2008), kanaat önderliği olarak etkileyiciler (Trepte ve Scherer 2010, Nisbet ve Kotcher 2009, Watts ve Dodds 2007), elektronik ağızdan ağıza pazarlamada etkileyicilerin rolleri (Liu ve ark. 2015, Wiedmann ve ark. 2010, Matsumura ve ark. 2008) gibi çeşitli perspektifler doğrultusunda çalışmaların vücut bulduğu; ulusal literatürde de benzer şekilde sosyal medya fenomenleri ve reklam ilişkisi (Avcılar ve ark. 2018, Aslan ve Ünlü 2016, Sabuncuoğlu ve Gülay 2014), sosyal medyada ağıdan ağıza pazarlama ve etkileyicilerin rolleri (Mert 2018, Yaylagül 2017), marka İletişimi ve etkileyiciler (Yaman 2018, Maden 2018, Alikılıç ve Özkan 2018, Uzunoğlu ve Kip 2014) gibi konular üzerine odaklanıldığı görülmektedir.

Uluslararası literatürde olduğu gibi ulusal literatürde de konuyla alakalı tezlerin artmaya başladığı gözlenmektedir. Yükseköğretim Kurulu Tez Merkezi web sitesinden (2019) etkileyiciler ve etkileyici kişi pazarlaması hakkında hazırlanmış tezlere bakıldığında; dokuzu yüksek lisans ve biri doktora olmak üzere toplamda on teze rastlanmaktadır. Bahsi geçen tezler, Instagram'da etkileyici kişi pazarlaması (Kolcuoğlu 2018), etkileyici kişi pazarlamasında kullanılan mesaj stratejileri (Aktaş 2018), etkileyici kişi pazarlamasının satın alma kararına etkisi (Özbek 2018), marka, ajans ve Youtuberlar bağlamında etkileyici kişi pazarlaması (Coşkun 2018), etkileyici kişi pazarlaması bağlamında Youtuberların iletişim stratejileri (Tahtalı 2018), Instagram Türkiye'de etkileyiciler ve etkileyici kişi pazarlaması (Büyükkuşoğlu 2017), etkileyicilerin tüketicilerin reklam algısına etkisi (Aydemir 2017), etkileyicilerin türeticilerin sosyal medya pazarlama aktivitelerine katılımlarına etkisi (Sözen 2016), etkileyicilerin yenilikçi ürünlerin yayılımındaki rolü (Uyar 2014), etkileyicilerin ve ağ kimliğinin yeni ürün benimsenmesi üzerindeki etkileri (Akdevelioğlu 2013) konularına odaklanmaktadır. Tezlerin ağırlıklı olarak 2017-2018 yıllarında hazırlandığı fark edilmekte, bu açıdan son yıllarda sosyal bilimcilerin konuya atfettikleri önem 
dikkat çekmektedir. Ayrıca son dönemlerde gerçekleştirilen sempozyum, panel ve konferans gibi bilimsel toplantıların yeni medya ile ilgili oturumlarında etkileyiciler ve etkileyici kişi pazarlaması konuları kendilerine yer bulmaktadır.

\section{YÖNTEM}

Bu başlık altında, alan araştırmasının temel hareket noktasını teşkil eden araştırma modeli, evren ve örneklem, veri toplamak üzere yararlanılan araçlar, elde edilen verilerin analizi için kullanılan testler ve açığa kavuşturulmak üzere ortaya konan araştırma sorularına ilişkin betimleyici bilgiler yer almaktadır.

\subsection{Araştırmanın Modeli}

Dijital çağla gelen bir pazarlama figürü olarak etkileyiciler üzerine odaklanan bu araştırma genel tarama modelinde olup, bağımlı ve bağımsız değişkenler arasında karşılaştırmalı ilişkisel taramalarda bulunmaktadır.

\subsection{Araştırmanın Uygulanması ve Örneklem}

Etkileyicilerin sahip olması istenen kriterleri ve takip edilme nedenlerini tespit etmek üzere 1-7 Mayıs 2018 tarihleri arasında Süleyman Demirel Üniversitesi öğrencileri üzerinde bir saha araştırması gerçekleştirilmiştir. Amaçlı örneklemin esas alındığı ve yüzyüze görüşme yöntemiyle verilerin toplandığı araştırmada, sahaya toplam 500 anket formu uygulanmıştır.

\subsection{Veri Toplama Araçları}

Etkileyicilere ve etkileyici takibine ilişkin genel kanaatler ile etkileyicilerde aranan kriterleri ve etkileyicilerin takip edilme nedenlerini ortaya koymak üzere 4 ana bölümden oluşan 46 soruluk bir anket formu hazırlanmıştır. İlk bölümde katılımcıların sosyo-demografik özelliklerini betimlemeye dönük 3 soru yer almakta; ikinci bölümde, etkileyicilere ve etkileyici takibine ilişkin genel kanaatleri içeren 7 soru bulunmaktadır. Üçüncü bölüm etkileyicilerde aranan kriterleri ortaya koymaya yönelik 5'li (1= kesinlikle katılmıyorum, 5= kesinlikle katılıyorum) likert skalasıyla oluşturulmuş 13 sorudan meydana gelirken; dördüncü bölüm etkileyicilerin takip edilme nedenlerine odaklanan $5^{\prime} l i \quad(1=$ kesinlikle 
katılmıyorum, 5= kesinlikle katılıyorum) likert skalası esas alınarak hazırlanmış 23 sorudan oluşmaktadır.

Anket formunun etkileyicilere ve etkileyici takibine ilişkin genel kanaatleri içeren kısmında Görgülü ve Farajova'nın (2017), etkileyicilerin takip edilme nedenlerine odaklanan kısmında ise Başer'in (2014) çalışmalarından esinlenilmiş ve yararlanılmıştır. Sahaya uygulama aşamasına geçmeden önce 50 kişilik bir örneklem grubu üzerinde ön teste tabi tutulan anket formu, anlaşllırlık, geçerlik ve analizlere uygunluk derecesi belirlenerek yeniden düzenlenmiş ve nihai şekline kavuşturulmuştur.

\subsection{Verilerin Analizi ve Kullanılan Testler}

Alan araştırmasından elde edilen verilerin istatistiksel olarak işlenmesinde SPSS (Statistical Package For Social Science) 24.0 istatistik programı kullanılmıştır. Verilerin analizinde sırasıyla, katılımcıların sosyo-demografik özelliklerine ve etkileyicilere ve etkileyici takibine ilişkin genel kanaatlerine ilişkin verileri ortaya koymak maksadıyla betimleyici istatistik teknikleri kullanılmıştır.

Araştırmaya katılanların etkileyicilere ve etkileyici takibine ilişkin genel kanaatlerinin sosyo-demografik özellikler açısından sergilediği farklılaşmayı tespit etmek amaciyla Ki Kare testi; etkileyicilerde aranan kriterler ve etkileyicilerin takip edilme nedenleri ile ilgili temel değişkenleri ortaya koymak üzere faktör analizi; söz konusu kriterler ile takip nedenlerinin kendi aralarındaki ilişki yönünü ve düzeyini belirlemek maksadıyla korelasyon analizi ve sosyodemografik özellikler bağlamında göstermiş olduğu farklılaşmayı gözler önüne sermek üzere ise bağımsız örneklem $t$ testi ve tek yönlü varyans analizi (ANOVA) kullanılmıştır.

\subsection{Araştırma Soruları}

Çalışmada aşağıdaki araştırma soruları cevaplanmaya çalışılmaktadır:

Araştırma Sorusu 1: Araştırmaya katılanların etkileyicilere ve etkileyici takibine ilişkin genel kanaatleri nelerdir ve bu kanaatler sosyo-demografik özelliklerden ne düzeyde etkilenmektedir? 
Araştırma Sorusu 2: Araştırmaya katılanların etkileyicilerde aradığı kriterler nelerdir?

Araştırma Sorusu 3: Etkileyicilerde aranan kriterler sosyo-demografik özellikler açısından nasıl bir dağılım göstermektedir?

Araştırma Sorusu 4: Araştırmaya katılanların etkileyicileri takip etme nedenleri nelerdir?

Araştırma Sorusu 5: Etkileyicilerin takip edilme nedenleri sosyo-demografik özellikler bağlamında nasıl bir dağılım sergilemektedir?

\section{ARAŞTIRMA BULGULARI}

\subsection{Sosyo-Demografik Özellikler}

Araştırmaya katılanlar sosyo-demografik özellikler itibariyle incelendiğinde; bu kişilerin \%50,2'si kadın, \%49,8'i erkektir. En düşük katılımcı yaşı 19, en yüksek katılımcı yaşı 24, katılımcıların yaşlarının aritmetik ortalaması 21,18, standart sapması 1,53'dür. Katılımcıların yaşları kategorize edildiğinde ise, \%39,8'inin 1920 arası, \%37,6'sının 21-22 arası ve \%22,6'sının 23-24 arası yaş grubunda yer aldığ1 fark edilmektedir. Araştırmaya katılanlar tarafından yapılan en düşük aylık ortalama harcama 350 TL, en yüksek 3000 TL, yapılan aylık ortalama harcamanın aritmetik ortalaması 1218,91 TL, standart sapması 494,23 TL'dir. Aylık ortalama harcamaya ilişkin bir kategorilendirmeye gidildiğinde ise, araştırmaya katılanların \%40’inın 501-1000 TL arası, \%32,4'ünün 1001-1500 TL arası, $\% 19,6$ 'sının $1501 \mathrm{TL}$ ve üzeri ve \%8'inin $500 \mathrm{TL}$ ve aşağısı aylık ortalama harcamasının olduğu anlaşılmaktadır.

\subsection{Etkileyicilere ve Etkileyici Takibine İlişkin Genel Kanaatler}

Bu başlık altında takip edilen etkileyici sayısı, etkileyicilerin ilk olarak takip edilmeye başlandığı sosyal medya ortamı, etkileyicilerin yerli ya da yabancı olmasına önem verme durumu, etkileyicilerin tanıtımlarının tesir ettiği alanlar, etkileyicilerin yerinde olmayı isteme durumu, bir markayı satın almadan önce etkileyicilerin tanıtım videolarını izleme durumu, etkileyicilerin marka tanıtımında veya pazarlamasında etkili olduğunu düşünme durumu, 
etkileyicilerin tanıtımları sayesinde son bir yıl içerisinde satın alınan marka sayısı ve bunların sosyo-demografik özellikler açısından gösterdiği farklılaşma üzerinde durulmaktadir.

\subsubsection{Takip Edilen Etkileyici Sayısı}

Takip edilen etkileyici sayısı açısından katılımcılar irdelendiğinde, bu kişilerin $\% 54,4^{\prime}$ ü sosyal medya ortamında 4 ve üzeri etkileyici takip ederken, $\% 45,4^{\prime} \ddot{u}$ 1-3 arası etkileyici takip etmekte, \%0,2'si ise bu konuya ilişkin herhangi bir görüş belirtmemektedir. Bu veriler ışığında, katılımcıların yarıdan fazlasının üçün üzerinde etkileyici takip ettiğini söylemek mümkündür.

Takip edilen etkileyici sayısının sosyo-demografik özellikler açısından göstermiş olduğu farklılaşma değerlendirildiğinde ise, cinsiyet $\left(X^{2}=, 04 ; s . d .=1 ; p>, 05\right)$, yaş $\left(X^{2}=1,11 ; s . d .=2 ; p>, 05\right)$ ve aylik ortalama harcama $\left(X^{2}=3,68 ; s . d .=3 ; p>, 05\right)$ açısından anlamlı hiçbir farklılaşmanın söz konusu olmadığı anlaşılmaktadır.

\subsubsection{Etkileyicilerin İlk Olarak Takip Edilmeye Başlandığı Sosyal Medya}

\section{Ortamı}

Etkileyicilerin ilk olarak takip edilmeye başlandığı sosyal medya ortamı değerlendirildiğinde, araştırmaya katılanların \%62,8'i etkileyicileri ilk olarak Instagram'dan takip etmeye başladığını belirtirken, \%20,6'sı diğer sosyal medya ortamlarından, \%11'i Twitter'dan ve \%5,6's1 Facebook'tan takip etmeye başladığını ifade etmektedir. Mevcut veriler doğrultusunda, etkileyicilerin sosyal medya ortamları içerisinde yoğunlukla ilk olarak Intagram'dan takip edilmeye başlandığı söylenebilir.

Etkileyicilerin ilk olarak takip edilmeye başlandığı sosyal medya ortamının sosyodemografik özellikler bağlamında ortaya koymuş olduğu farklılaşma bir incelemeye tabi tutulduğunda ise, cinsiyet $\left(X^{2}=30,56 ;\right.$ s.d. $\left.=3 ; p<, 001\right)$ ve aylik ortalama harcama $\left(X^{2}=24,32 ;\right.$ s.d. $=9 ; \quad p<$,005) bakımından anlamlı bir farklılaşmanın gözlendiği, buna karşın yaş $\left(X^{2}=3,42 ;\right.$ s.d. $\left.=6 ; p>, 05\right)$ bakımından anlamlı bir farklılaşmanın ortaya çıkmadığı görülmektedir.

Tablo 1'deki verilerden hareketle farklılaşma durumu ele alındığında ise, 
Etkileyicileri ilk olarak kadınların \%5,6'sı Facebook'tan, \%74,1'i Instagram'dan, $\% 7,2$ 'si Twitter'dan ve \%13,1'i diğer sosyal medya ortamlarından takip etmeye başlarken; erkeklerin \%5,6'sı Facebook'tan, \%51,4'ü Instagram'dan, \%14,9’u Twitter'dan ve \%28,1'i diğer sosyal medya ortamlarından takip etmeye başlamaktadır. Bu bağlamda, kadınların ilk olarak etkileyici takibine başladığı sosyal medya ortamı yoğunlukla Instagram olurken, erkekler Instagram'ın yanı sıra diğer sosyal medya ortamlarından da etkileyici takibine başlamaktadır.

Etkileyicileri ilk olarak aylık ortalama harcaması 500 TL ve aşağısında olanların \%20'si Facebook'tan, \%57,5'i Instagram'dan, \%5'i Twitter'dan ve \%17,5'i diğer sosyal medya ortamlarından takip etmeye başlarken; aylık ortalama harcaması 501-1000 TL arasında bulunanların \%2'si Facebook'tan, \%64'ü Instagram'dan, \%10,5'i Twitter'dan ve \%23,5'i diğger sosyal medya ortamlarından; aylık ortalama 1001-1500 TL arası harcama yapanları \%7,4'ü Facebook'tan, \%62,3'ü Instagram'dan, \%11,7'si Twitter'dan ve \%18,5'i diğger sosyal medya ortamlarından; aylık ortalama 1500 TL ve üzeri harcaması olanların \%4,1'i Facebook'tan, \%63,3’ü Instagram'dan, \%13,3'ü Twitter' dan ve \%19,4'ü diğer sosyal medya ortamlarından takibe başlamaktadır. Bu verilerden de anlaşılacağı üzere, aylık ortalama harama itibariyle tüm gruplarda etkileyicilerin ilk olarak takip edilmeye başlandığg sosyal medya ortamı olarak Instagram çok ön plana çıkmakla birlikte, aylık ortalama harcama miktarında meydana gelen artışla beraber Facebook'un etkileyicilerin ilk olarak takip edilmeye başlandığı sosyal medya ortamı olma özelliğinde bir düşüş meydana gelirken, Instagram, Twitter ve diğer sosyal medya ortamlarında artış yaşanmaktadır. 
Tablo 1: Etkileyicilerin İlk Olarak Takip Edilmeye Başlandığı Sosyal Medya Ortamının Sosyo-Demografik Özellikler Açısından Sergilediği Farklılaşma

\begin{tabular}{|c|c|c|c|c|}
\hline & 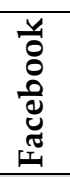 & 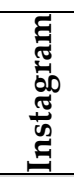 & 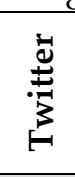 & 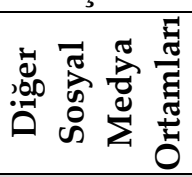 \\
\hline Cinsiyet & \multicolumn{4}{|c|}{$X^{2}=30,56 ;$ s.d. $=3 ; p<, 001$} \\
\hline Kadın & 5,6 & 74,1 & 7,2 & 13,1 \\
\hline Erkek & 5,6 & 51,4 & 14,9 & 28,1 \\
\hline Aylık Ortalama Harcama & \multicolumn{4}{|c|}{$X^{2}=24,32 ; s . d .=9 ; p<, 005$} \\
\hline 500 TL ve Aşağısı & 20 & 57,5 & 5 & 17,5 \\
\hline 501-1000 TL Arası & 2 & 64 & 10,5 & 23,5 \\
\hline 1001-1500 TL Arası & 7,4 & 62,3 & 11,7 & 18,5 \\
\hline 1501 TL ve Üzeri & 4,1 & 63,3 & 13,3 & 19,4 \\
\hline
\end{tabular}

\subsubsection{Etkileyicilerin Yerli ya da Yabancı Olmasına Önem Verme Durumu}

Etkileyicilerin yerli ya da yabancı olmasına önem verme durumu ele alındığında, katılımcıların \%64,2'si bu durumun kendileri için önemli olmadığını belirtirken, \%35'i önemli görmekte, \%0,8'i ise konuya ilişkin bir görüş beyan etmemektedir. $\mathrm{Bu}$ verilerden hareketle, etkileyicilerin yerli ya da yabancı olmasının çok fazla önemli olmadığını ifade etmek mümkündür.

Etkileyicilerin yerli ya da yabancı olmasına önem verme durumunun sosyodemografik özellikler doğrultusunda sergilemiş olduğu farklılaşma incelendiğinde ise, cinsiyet $\left(X^{2}=1,09 ; s . d .=1 ; p>, 05\right)$, yaş $\left(X^{2}=1,91 ; s . d .=2 ; p>, 05\right)$ ve aylık ortalama harcama $\left(X^{2}=4,98 ;\right.$ s.d. $\left.=3 ; p>, 05\right)$ yönünden anlamlı hiçbir farklılaşmanın gözlenmediği ortaya çıkmaktadır.

\subsubsection{Etkileyicilerin Tanıtımlarının Tesir Ettiği Alanlar}

Etkileyicilerin tanıtımlarının tesir ettiği alanlar itibariyle araştırmaya katılanlara bakıldığında, \%64,6'sı sanat-eğlence alanında, \%38,8'i kıyafet alanında ve kişisel bakım-kozmetik alanında, \%38,4'ü turizm-seyahat alanında, \%23,2'si yeme-içme alanında, \%21,6's1 aksesuar alanında, \%20,8'i elektronik aletler alanında, \%19,6's1 spor malzemeleri alanında, \%15'i sağlık alanında, \%7,2'si anne-çocuk alanında ve \%12,8'i bu kategoriler dışında kalan diğer alanlarda etkileyicilerin tanıtımlarının tesirinde kaldığı yönünde görüş belirtmektedir. Buradan hareketle, etkileyicilerin 
en fazla sanat-eğlence, kıyafet, kişisel bakım-kozmetik ve turizm-seyahat alanlarındaki tanıtımlarının tesirli olurken, en az anne-çocuk ve sağlık alanlarındaki tanıtımlarının tesir uyandırdığı belirtilebilir.

Etkileyicilerin tanıtımlarının tesir ettiği alanların sosyo-demografik özellikler yönünden gösterdiği farklılaşma ele alındığında, kıyafet alanında cinsiyet $\left(X^{2}=\right.$ $67,05 ;$ s.d. $=1 ; p<, 001)$ ve yaş $\left(X^{2}=6,09 ;\right.$ s.d. $\left.=2 ; p<, 05\right)$ açısından, kişisel bakımkozmetik alanında cinsiyet $\left(X^{2}=177,63 ;\right.$ s.d. $\left.=1 ; p<, 001\right)$ açısından, aksesuar alanında cinsiyet $\left(X^{2}=14,94 ;\right.$ s.d. $\left.=1 ; p<, 001\right)$ ve yaş $\left(X^{2}=7,81 ;\right.$ s.d. $\left.=2 ; p<, 05\right)$ açısından, elektronik aletler alanında cinsiyet $\left(X^{2}=26,15 ;\right.$ s.d. $\left.=1 ; p<, 001\right)$ açısından, spor malzemeleri alanında cinsiyet $\left(X^{2}=20,70 ; s . d .=1 ; p<, 001\right)$ açısından, turizmseyahat alanında cinsiyet $\left(X^{2}=5,38 ;\right.$ s.d. $\left.=1 ; p<, 05\right)$ açısından, sanat-eğlence alanında aylık ortalama harcama $\left(X^{2}=16,45 ; s . d .=3 ; p<, 005\right)$ açısından, anne-çocuk alanında cinsiyet $\left(X^{2}=5,74 ; s . d .=1 ; p<, 05\right)$ açısından ve bu kategoriler dışında kalan diğer alanlarda cinsiyet $\left(X^{2}=23,55 ;\right.$ s.d. $\left.=1 ; p<, 001\right)$ açısından anlamlı bir farklılaşma ortaya çıkarken, yine kıyafet alanında aylık ortalama harcama $\left(X^{2}=, 23 ;\right.$ s.d. $=3$; $p>$ ,05) bakımından, kişisel bakım-kozmetik alanında yaş $\left(X^{2}=3,84 ; s . d .=2 ; p>, 05\right)$ ve aylık ortalama harcama $\left(X^{2}=1,45 ; s . d .=3 ; p>, 05\right)$ bakımından, aksesuar alanında aylık ortalama harcama $\left(X^{2}=4,18 ;\right.$ s.d. $\left.=3 ; p>, 05\right)$ bakımından, elektronik aletler alanında yaş $\left(X^{2}=, 18 ;\right.$ s.d. $\left.=2 ; p>, 05\right)$ ve aylık ortalama harcama $\left(X^{2}=, 33 ;\right.$ s.d. $=3 ; p>$ ,05) bakımından, spor malzemeleri alanında yaş $\left(X^{2}=1,34 ; s . d .=2 ; p>, 05\right)$ ve aylık ortalama harcama $\left(X^{2}=1,76 ;\right.$ s.d. $\left.=3 ; p>, 05\right)$ bakımından, turizm-seyahat alanında yaş $\left(X^{2}=, 49 ;\right.$ s.d. $\left.=2 ; p>, 05\right)$ ve aylık ortalama harcama $\left(X^{2}=4,61 ; s . d .=3 ; p>, 05\right)$ bakımından, yeme-içme alanında cinsiyet $\left(X^{2}=1,02 ;\right.$ s.d. $\left.=1 ; p>, 05\right)$, yaş $\left(X^{2}=, 54\right.$; s.d.= 2; $p>, 05)$ ve aylık ortalama harcama $\left(X^{2}=2,17 ; s . d .=3 ; p>, 05\right)$ bakımından, sağlık alanında cinsiyet $\left(X^{2}=1,79 ; s . d .=1 ; p>, 05\right)$, yaş $\left(X^{2}=, 49 ; s . d .=2 ; p>, 05\right)$ ve aylık ortalama harcama $\left(X^{2}=3,53 ; s . d .=3 ; p>, 05\right)$ bakımından, sanat-eğelence alanında cinsiyet $\left(X^{2}=, 001 ; s . d .=1 ; p>, 05\right)$ ve yaş $\left(X^{2}=4,40 ; s . d .=2 ; p>, 05\right)$ bakımından, anneçocuk alanında yaş $\left(X^{2}=, 78 ;\right.$ s.d. $\left.=2 ; p>, 05\right)$ ve aylık ortalama harcama $\left(X^{2}=3,53\right.$; s.d.= 3; $p>, 05)$ bakımından ve bu kategoriler dışında kalan diğer alanlarda yaş $\left(X^{2}=\right.$ 
,03; s.d.= 2; $p>, 05)$ ve aylik ortalama harcama $\left(X^{2}=, 31 ; s . d .=3 ; p>, 05\right)$ bakımından anlamlı bir farklılaşmayla karşılaşılmadığı müşahede edilmektedir.

Tablo 2 doğrultusunda farklılaşma durumu incelendiğinde ise, Kıyafet alanında, kadınların \%56,6'sı ve erkeklerin \%20,9'u; 19-20 yaş arasında bulunanların \%44,2'si, 21-22 yaş arasında bulunanların \%38,3'ü ve 23-24 yaş arasında bulunanların \%30,1'i etkileyicilerin tanıtımlarının tesirinde kalırken; yine kadınların \%43,4'ü ve erkeklerin \%79,1'í; 19-20 yaş arasındakilerin $\% 55,8^{\prime}$ si, 21-22 yaş arasındakilerin \%61,7'si ve 23-24 yaş arasındakilerin \%69,9'u söz konusu tanıtımlardan etkilenmemektedir. Bu doğrultuda, kıyafet alanında kadınlar erkeklere nazaran etkileyicilerin tanıtımlarının tesirinde daha fazla kalmakta, yaş ilerledikçe etkileyicilerin kıyafet alanındaki tanıtımlarının tesiri azalmaktadır.

Kişisel bakım-kozmetik alanında, kadınların \%67,7'si ve erkeklerin \%9,6'sı etkileyicilerin tanıtımlarının tesiri altında kalırken, yine kadınların \%32,3'ü ve erkeklerin \%90,4'ü bu tanıtımların tesirinde kalmamaktadır. Bu bağlamda, kişisel bakım-kozmetik alanında kadınlar erkeklere kıyasla etkileyicilerin tanıtımlarının tesiri altında daha fazla kalmaktadır.

Aksesuar alanında, kadınların \%28,7'sinin ve erkeklerin \%14,5'inin; $19-20$ yaş aralığındakilerin \%27,6'sının, 21-22 yaş aralığındakilerin \%19,1'inin ve 23-24 yaş aralığındakilerin \%15'inin üzerinde etkileyicilerin tanitımlarının tesiri bulunurken; yine kadınların \%71,3'ünün ve erkeklerin \%85,5'inin; 19-20 yaş aralığında yer alanların \%72,4'ünün, 21-22 yaş aralığında yer alanların \%80,9'unun ve 23-24 yaş aralığında yer alanların \%85'inin üzerinde böyle bir tesirden söz edilememektedir. Bu minvalde, aksesuar alanında etkileyicilerin tanıtımlarının erkeklerden ziyade kadınlar üzerinde daha fazla tesiri bulunmakta, yaş ilerledikçe etkileyicilerin aksesuar alanındaki tanıtımlarının tesiri azalmaktadır.

Elektronik aletler alanında, kadınların \%11,6'sı ve erkeklerin \%30,1'i etkileyicilerin tanitımlarının tesirini hissederken, yine kadınların \%88, $4^{\prime} \ddot{\mathrm{ü}}$ ve erkeklerin $\% 69,9^{\prime} \mathrm{u}$ bu tesiri hissetmemektedir. Bu noktada, elektronik aletler alanında erkekler kadınlara nazaran etkileyicilerin tanıtımlarının tesirini daha fazla hissetmektedir. 
Spor malzemeleri alanında, kadınların \%11,6'sı ve erkeklerin \%27,7'si etkileyicilerin tanıtımlarının tesiriyle hareket ederken, yine kadınların \%88,4'ü ve erkeklerin \%72,3'ü böyle bir tesirden bağımsız hareket etmektedir. Bu bulgular doğrultusunda, spor malzemeleri alanında erkekler kadınlara oranla etkileyicilerin tanıtımlarının tesiriyle daha fazla hareket etmektedir.

Turizm-seyahat alanında, kadınların \%43,4'ü ve erkeklerin \%33,3'ü etkileyicilerin tanitımlarının tesirinde kalırken, yine kadınların \%56,6's1 ve erkeklerin $\% 66,7^{\prime}$ si bu tanitımların tesiri altına girmemektedir. Söz konusu bulgulardan hareketle, kadınlar erkeklere göre etkileyicilerin turizm-seyahat alanındaki tanıtımlarının tesirinde daha fazla kalmaktadır.

Sanat-eğlence alanında, aylık ortalama harcaması 500 TL ve aşağısında olanların \%55'i, 501-1000 TL arasında olanların \%73,5'i, 1001-1500 TL arasında olanların \%64,2'si ve 1501 TL ve üzerinde olanların \%51'i etkileyicilerin tanıtımlarının tesiri altında kalırken, yine aylık ortalama harcaması 500 TL ve aşağısındakilerin \%45'i, 501-1000 TL arasındakilerin \%26,5'i, 1001-1500 TL arasındakilerin \%35,8'i ve 1501 TL ve üzerindekilerin $\% 49$ 'u bu tanitımların tesiri altında kalmamaktadır. Bu bulgulardan yola çıkıldığında, aylık ortalama harcaması 501-1000 TL arasında bulunanlar ile 1001-1500 TL arasında bulunanlar, 1501 TL ve üzerinde bulunanlar ile $500 \mathrm{TL}$ ve aşağısında bulunanlara kıyasla etkileyicilerin sanat-eğlence alanındaki tanıtımlarının daha fazla tesiri altında kalmaktadır.

Anne-çocuk alanında, kadınların \%10'u ve erkeklerin $\% 4,4^{\prime} \ddot{u}$ üzerinde etkileyicilerin tanıtımları tesirli olurken, yine kadınların \%90'ı ve erkeklerin \%95,6's1 üzerinde bu tanıtımlar tesirli olmamaktadır. Söz konusu bulgulardan hareketle, anne-çocuk alanında etkileyicilerin tanıtımları erkeklerden ziyade kadınlar üzerinde daha tesirli olmaktadır.

Yukarıda bahsi geçen kategoriler dışında kalan diğer alanlarda, kadınların \%5,6'sı ve erkeklerin \%20,1'i üzerinde etkileyicilerin tanıtımları tesir uyandırırken, yine kadınların \%94,4'ünde ve erkeklerin \%79,9'unda bahsi geçen tanitımlar tesir uyandırmamaktadır. Bu doğrultuda, etkileyicilerin yukarıda bahsi geçen 
Dijital Çağın Bir Pazarlama ve Marka İletişim Aracı Olarak Etkileyiciler: Kanaatler, ...

kategoriler dışında kalan diğer alanlardaki tanıtımları erkeklerde kadınlara göre daha fazla tesir uyandırmaktadır.

Tablo 2: Etkileyicilerin Tanıtımlarının Tesir Ettiği Alanların Sosyo-Demografik Özellikler Açısından Sergilediği Farklılaşma

\begin{tabular}{|c|c|c|c|}
\hline & & $\underset{d}{\Delta}$ & 胥 \\
\hline \multirow{7}{*}{ Kiyafet } & Cinsiyet & \multicolumn{2}{|c|}{$X^{2}=67,05 ; s . d .=1 ; p<, 001$} \\
\hline & Kadın & 56,6 & 43,4 \\
\hline & Erkek & 20,9 & 79,1 \\
\hline & Yaş & \multicolumn{2}{|c|}{$X^{2}=6,09 ;$ s.d. $=2 ; p<, 05$} \\
\hline & 19-20 Yaş Arası & 44,2 & 55,8 \\
\hline & 21-22 Yaş Arası & 38,3 & 61,7 \\
\hline & 23-24 Yaş Arası & 30,1 & 69,9 \\
\hline \multirow{3}{*}{$\begin{array}{l}\text { Kişisel Bakım- } \\
\text { Kozmetik }\end{array}$} & Cinsiyet & \multicolumn{2}{|c|}{$X^{2}=177,63 ;$ s.d. $=1 ; p<, 001$} \\
\hline & Kadın & 67,7 & 32,3 \\
\hline & Erkek & 9,6 & 90,4 \\
\hline \multirow{7}{*}{ Aksesuar } & Cinsiyet & \multicolumn{2}{|c|}{$X^{2}=14,94 ;$ s.d. $=1 ; p<, 001$} \\
\hline & Kadın & 28,7 & 71,3 \\
\hline & Erkek & 14,5 & 85,5 \\
\hline & Yaş & \multicolumn{2}{|c|}{$X^{2}=7,81 ;$ s.d. $=2 ; p<, 05$} \\
\hline & 19-20 Yaş Arası & 27,6 & 72,4 \\
\hline & 21-22 Yaş Arası & 19,1 & 80,9 \\
\hline & 23-24 Yaş Arası & 15 & 85 \\
\hline \multirow{3}{*}{$\begin{array}{c}\text { Elektronik } \\
\text { Aletler }\end{array}$} & Cinsiyet & \multicolumn{2}{|c|}{$X^{2}=26,15 ;$ s.d. $=1 ; p<, 001$} \\
\hline & Kadın & 11,6 & 88,4 \\
\hline & Erkek & 30,1 & 69,9 \\
\hline \multirow{3}{*}{$\begin{array}{c}\text { Spor } \\
\text { Malzemeleri }\end{array}$} & Cinsiyet & \multicolumn{2}{|c|}{$X^{2}=20,70 ; s . d .=1 ; p<, 001$} \\
\hline & Kadin & 11,6 & 88,4 \\
\hline & Erkek & 27,7 & 72,3 \\
\hline \multirow{3}{*}{$\begin{array}{l}\text { Turizm- } \\
\text { Seyahat }\end{array}$} & Cinsiyet & \multicolumn{2}{|c|}{$X^{2}=5,38 ;$ s.d. $=1 ; p<, 05$} \\
\hline & Kadın & 43,4 & 56,6 \\
\hline & Erkek & 33,3 & 66,7 \\
\hline \multirow{5}{*}{ Sanat-Eğlence } & Aylık Ortalama Harcama & \multicolumn{2}{|c|}{$X^{2}=16,45 ;$ s.d. $=3 ; p<, 005$} \\
\hline & 500 TL ve Aşağ 1 sı & 55 & 45 \\
\hline & 501-1000 TL Aras1 & 73,5 & 26,5 \\
\hline & 1001-1500 TL Arası & 64,2 & 35,8 \\
\hline & 1501 TL ve Üzeri & 51 & 49 \\
\hline \multirow[t]{3}{*}{ Anne-Çocuk } & Cinsiyet & \multicolumn{2}{|c|}{$X^{2}=5,74 ; s . d .=1 ; p<, 05$} \\
\hline & Kadın & 10 & 90 \\
\hline & Erkek & 4,4 & 95,6 \\
\hline \multirow{3}{*}{$\begin{array}{l}\text { Bu Kategoriler } \\
\text { Dişındakiler }\end{array}$} & Cinsiyet & \multicolumn{2}{|c|}{$X^{2}=23,55 ;$ s.d. $=1 ; p<, 001$} \\
\hline & Kadın & 5,6 & 94,4 \\
\hline & Erkek & 20,1 & 79,9 \\
\hline
\end{tabular}




\subsubsection{Etkileyicilerin Yerinde Olmayı İsteme Durumu}

Etkileyicilerin yerinde olmayı isteme durumu açısından katılımcılar irdelendiğinde, bu kişilerin \%50,2'si herhangi bir etkileyicinin yerinde olmayı istemediğini belirtirken, \%49,8'i böyle bir isteğinin olduğunu ifade etmektedir. Bu verilere dayanarak, etkileyicilerin yerinde olmak konusunda yarı yarıya bir görüş ayrılığının bulunduğu, bu noktada da geneli kapsayan bir isteklilik durumunun söz konusu olmadığı sonucuna varmak mümkündür.

Etkileyicilerin yerinde olmayı isteme durumunun sosyo-demografik özellikler bağlaminda gösterdiği farklılaşma değerlendirildiğinde ise, sadece yaş $\left(X^{2}=8,53\right.$; $s . d .=2 ; p<, 05)$ açısından anlamlı bir farklılaşmanın söz konusu olduğu, buna karşın cinsiyet $\left(X^{2}=1,56 ;\right.$ s.d. $\left.=1 ; p>, 05\right)$ ve aylik ortalama harcama $\left(X^{2}=1,83 ; s . d .=3 ; p>, 05\right)$ yönünden anlamlı bir farklılaşmanın ortaya çıkmadığı görülmektedir.

Tablo 3 referans alınarak farklılaşma durumu analiz edildiğinde, 19-20 yaş aralığında bulunanların \%57,8'i, 21-22 yaş aralığında bulunanların \%45,2'si ve 2324 yaş aralığında bulunanların \%43,4'ü etkileyicilerin yerinde olmayı isterken, yine 19-20 yaş aralığındakilerin \%57,8'i, 21-22 yaş aralığındakilerin \%45,2' si ve 2324 yaş aralığındakilerin \%43,4’ü böyle bir isteğe sahip değildir. Mevcut verilerden yola çıkarak, yaş ilerledikçe etkileyicilerin yerinde olmayı isteme durumunda bir azalma meydana gelmektedir.

Tablo 3: Etkileyicilerin Yerinde Olmayı İsteme Durumunun Sosyo-Demografik Özellikler Açısından Sergilediği Farklılaşma

\begin{tabular}{|c|c|c|}
\hline & 离 & $\underset{\mathbb{Z}}{\grave{I}}$ \\
\hline Yaş & \multicolumn{2}{|c|}{$X^{2}=8,53 ;$ s.d. $=2 ; p<, 05$} \\
\hline 19-20 Yaş Arası & 57,8 & 42,2 \\
\hline 21-22 Yaş Arası & 45,2 & 54,8 \\
\hline 23-24 Yaş Arası & 43,4 & 56,6 \\
\hline
\end{tabular}




\subsubsection{Bir Markayı Satın Almadan Önce Etkileyicilerin Tanıtım Videolarını İzleme Durumu}

Bir markayı satın almadan önce etkileyicilerin tanıtım videolarını izleme durumu itibariyle araştırmaya katılanlara bakıldığında, \%40,8'i bir markayı satın almadan önce etkileyicilerin tanıtım videolarını izlemeye ürüne göre karar verdiğini vurgularken, \%29,8'i bu süreçte söz konusu tanıtım videolarını izlemediğini ve $\% 29,2$ 'si izlediğini ifade etmekte, \%0,2'si ise konuya ilişkin görüş belirtmemektedir. Buradan hareketle, bir markayla ilgili satın alma davranışını gerçekleştirmeden önce etkileyicilerin tanıtım videolarının izlenmesinde/izlenmemesinde daha çok satın alınmak istenen ürünün belirleyici olduğu çıkarsanabilir.

Bir markayı satın almadan önce etkileyicilerin tanıtım videolarını izleme durumunun sosyo-demografik özellikler yönünden sahip olduğu farklılaşma irdelendiğinde, yalnızca cinsiyet $\left(X^{2}=7,80 ; s . d .=2 ; p<, 05\right)$ açısından anlamlı bir farklılaşma söz konusu olurken, yaş $\left(X^{2}=6,51 ;\right.$ s.d. $\left.=4 ; p>, 05\right)$ ve aylık ortalama harcama $\left(X^{2}=1,59 ;\right.$ s.d. $=6 ; p>$,05) bakımından anlamlı bir farklılaşmaya rastlanamamaktadır.

Tablo 4'teki veriler kapsamında farklılaşma durumuna bakıldığında, kadınların $\% 32,7^{\prime}$ si ve erkeklerin \%25,8'i bir markayı satın almadan önce etkileyicilerin tanıtım videolarını izlerken, kadınların \%24,3’ü ve erkeklerin \%35,5'i böyle bir davranış içerisine girmemekte, bununla birlikte kadınların \%43'ü ve erkeklerin \%38,7'si ise söz konusu davranışlarının ürüne göre değiştiğini belirtmektedir. Bu bağlamda, kadınlar bir markayı satın almadan önce etkileyicilerin tanıtım videolarını erkeklere oranla daha fazla izlemektedir.

Tablo 4: Bir Markayı Satın Almadan Önce Etkileyicilerin Tanıtım Videolarını İzleme Durumunun Sosyo-Demografik Özellikler Açısından Sergilediği Farklılaşma

\begin{tabular}{|c|c|c|c|}
\hline & $\begin{array}{l}\vec{\Phi} \\
\vec{\nabla}\end{array}$ & $\underset{\vec{I}}{\stackrel{\Xi}{I}}$ & 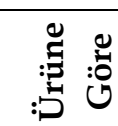 \\
\hline Cinsiyet & \multicolumn{3}{|c|}{$X^{2}=7,80 ; s . d .=2 ; p<, 05$} \\
\hline Kadın & 32,7 & 24,3 & 43 \\
\hline Erkek & 25,8 & 35,5 & 38,7 \\
\hline
\end{tabular}




\subsubsection{Etkileyicilerin Marka Tanıtımında veya Pazarlamasında Etkili Olduğunu}

\section{Düşünme Durumu}

Etkileyicilerin marka tanıtımında veya pazarlamasında etkili olduğunu düşünme durumu değerlendirildiğinde, araştırmaya katılanların \%85,4'ü marka tanitımında veya pazarlamasında etkileyicilerin tesirini kabul ederken, \%14,4'ü bu görüşü paylaşmamakta, \%0,2'si ise herhangi bir fikir beyan etmemektedir. Mevcut veriler doğrultusunda, yaygın kanaatin etkileyicilerin marka tanıtımında veya pazarlamasında etkisinin bulunduğu yönünde olduğu söylenebilir.

Etkileyicilerin marka tanıtımında veya pazarlamasında etkili olduğunu düşünme durumunun sosyo-demografik özellikler bağlamında göstermiş olduğu farklılaşma incelendiğinde ise, sadece cinsiyet $\left(X^{2}=5,15 ;\right.$ s.d. $\left.=1 ; p<, 05\right)$ bakımından anlamlı bir farklılaşmanın bulunduğu, buna karşın yaş $\left(X^{2}=, 57 ;\right.$ s.d. $\left.=2 ; p>, 05\right)$ ve aylık ortalama harcama $\left(X^{2}=3,28 ;\right.$ s.d. $=3 ; p>$,05) yönünden anlamlı bir farklılaşmanın ortaya çıkmadığı görülmektedir.

Tablo 5'te yer verilen analiz sonuçları bağlamında farklılaşma durumu ele alındığında, kadınların \%89,2'si ve erkeklerin \%81,9'u etkileyicilerin marka tanitımında veya pazarlamasında etkili olduğunu düşünürken, yine kadınların \%10,8'i ve erkeklerin \%18,1'i bu görüşü paylaşmamaktadır. Buradan da anlaşılacağı üzere, kadınlar erkeklere nazaran etkileyicilerin marka tanıtımında veya pazarlamasında etkili olduğunu daha fazla düşünmektedir.

Tablo 5: Etkileyicilerin Marka Tanıtımında veya Pazarlamasında Etkili Olduğunu Düşünme Durumunun Sosyo-Demografik Özellikler Açısından Sergilediği Farklılaşma

\begin{tabular}{|l|c|c|}
\hline & 离 & 空 \\
\hline Cinsiyet & $X^{2}=5,15 ;$ s.d. $=1 ; p<, 05$ \\
\hline Kadın & 89,2 & 10,8 \\
\hline Erkek & 81,9 & 18,1 \\
\hline
\end{tabular}




\subsubsection{Etkileyicilerin Tanıtımları Sayesinde Son Bir Yıl İçerisinde Satın Alınan}

\section{Marka Sayısı}

Etkileyicilerin tanıtımları sayesinde son bir yıl içerisinde satın alınan marka sayısı ortaya konulmak istendiğinde, katılımcıların \%52,2'si hiç marka satın almadığını belirtirken, \%36,4'ü 1-3 arası ve \%11,4'ü 4 ve üzeri marka satın aldığını ifade etmektedir. Bu bağlamda, etkileyicilerin tanıtımlarının satın alma davranışı üzerinde bir etkisinin olduğu çıkarımında bulunmak mümkündür.

Etkileyicilerin tanıtımları sayesinde son bir yıl içerisinde satın alınan marka sayısının sosyo-demografik özellikler doğrultusunda sergilediği farklılaşma ele alındığında ise, yalnızca cinsiyet $\left(X^{2}=30,03 ; s . d .=2 ; p<, 001\right)$ açısından anlamlı bir farklılaşmanın olduğu, bununla birlikte yaş $\left(X^{2}=2,52 ; s . d .=4 ; p>, 05\right)$ ve aylık ortalama harcama $\left(X^{2}=6,93 ; s . d .=6 ; p>, 05\right)$ açısından anlamlı bir farklılaşmanın bulunmadığı anlaşılmaktadır.

Tablo 6'daki verilerden yola çıkarak farklılaşma durumu ortaya konmak istendiğinde, kadınların \%43'ü ve erkeklerin \%61,4'ü etkileyicilerin tanıtımları sayesinde son bir yıl içerisinde hiç marka satın almazken, kadıların \%38,6'sı ve erkeklerin \%34,1'i 1-3 arası, yine kadınların \%18,3'ü ve erkeklerin \%4,4’ü 4 ve üzeri marka satın aldığını dile getirmektedir. Bu veriler minvalinde, etkileyicilerin tanıtımlarının kadınların satın alma davranışları üzerindeki tesiri erkeklere göre daha fazladır.

Tablo 6: Etkileyicilerin Tanıtımları Sayesinde Son Bir Yıl İçerisinde Satın Alınan Marka Sayısının Sosyo-Demografik Özellikler Açısından Sergilediği Farklılaşma

\begin{tabular}{|c|c|c|c|}
\hline & 谣 & 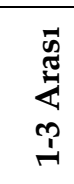 & 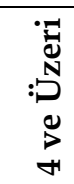 \\
\hline Cinsiyet & \multicolumn{3}{|c|}{$X^{2}=30,03 ;$ s.d. $=2 ; p<, 001$} \\
\hline Kadın & 43 & 38,6 & 18,3 \\
\hline Erkek & 61,4 & 34,1 & 4,4 \\
\hline
\end{tabular}




\subsection{Etkileyicilerde Aranan Kriterlere İlişkin Görüşler}

$\mathrm{Bu}$ başlık altında etkileyicilerde aranan kriterler ve bu kriterlerin sosyodemografik özellikler açısından sergilediği farklılaşma ele alınmaktadır.

\subsubsection{Etkileyicilerde Aranan Kriterler}

Sosyal medya ortamında tüketicilerin/takipçilerin, etkileyicilerde aradıkları kriterlere ilişkin temel değişkenleri saptamak ve çalışmanın teorik çerçevesinde ortaya konan bilgilerle alan araştırmasından elde edilen sonuçların ne düzeyde örtüştügünü tespit etmek maksadıyla, "kesinlikle katılmıyorum”dan, “kesinlikle katılıyorum"a doğru sıralanan 5'li Likert skalasıyla hazırlanmış 13 yargıya (item) verilen cevaplar bağlamında faktör analizi gerçekleştirilmiş, faktör analizi neticesinde çalışmanın teorik çerçevesiyle de benzerlik arz eden 3 faktör grubunun ele alınabildiği gözlenmiştir. Tablo 7'de betimlenen verilerden de fark edileceği üzere, bu faktörlerden birincisi “Tarza İlişkin Kriterler Faktörü", ikincisi "Fiziki Görünüşe İlişkin Kriterler Faktörü” ve üçüncüsü “Yetkinliğe İlişkin Kriterler Faktörü" olarak adlandırılmıştır. Faktör gruplarının sınıflandırılması ve değerlendirilmesi süreçlerinde varimax rotasyonlu tablo dikkate alınmıştır. Faktör analizine sokulan maddelerin güvenirlik katsayısı (Cronbach's $\alpha=, 722$ ) genel olarak yüksek bulunmuştur. Faktörlerin her birinin güvenirlik katsayısının ise, birinci faktör için $(, 732)$, ikinci faktör için $(, 618)$ ve üçüncü faktör için $(, 503)$ gibi uygun değerler aldığı görülmüştür.

Faktör analizi sonucunda birinci faktörü açıklayan toplam 4 madde tespit edilmiştir. Bunlar; "Etkileyicilerin Eğlenceli Olması Benim İçin Önemlidir", “Etkileyicilerin Dürüst ve Samimi Olması Benim İçin Önemlidir”, “Etkileyicilerin Jest ve Mimikleri Benim İçin Önemlidir" ve "Etkileyicilerin Çektiği Videoların İçeriği Benim İçin Önemlidir" ifadelerine yer veren maddelerdir. Bu maddeler etkileyicilerin tüketicilere/takipçilerine yönelik tanıtım materyallerini hazırlayış ve sunuş biçimlerine odaklanan, her etkileyicinin benimsediği üslup doğrultusunda farklılaşabilen ve yaptığı tanıtımı kendine özgü hale getiren ve dolayısıyla da onun tarzını yansıtan ifadeler olduğu için bu faktör “Tarza İlişkin 
Dijital Çağın Bir Pazarlama ve Marka İletişim Aracı Olarak Etkileyiciler: Kanaatler, ...

Kriterler Faktörü" olarak isimlendirilmiştir ve toplam varyansın \%22,87'sini açıklamaktadır.

Çalışmada ikinci faktörü açıklayan 3 madde saptanmıştır. Bunlar; “Etkileyicilerin Fiziksel Olarak Çekici Olması Benim İçin Önemlidir”, "Etkileyicilerin Giydikleri Kıyafetler Benim İçin Önemlidir" ve "Etkileyicilerin Cinsiyeti Benim İçin Önemlidir" ifadelerini içeren maddelerdir. İfadelerden de fark edileceği üzere, ilgili maddeler etkileyicilerin dış görünüşü üzerine odaklanan, özellikle ilk izlenimler üzerinde etkisi bulunan fiziki özelliklere vurgu yapan yargılar içermektedir. Bundan ötürü de söz konusu faktör “Fiziki Görünüşe İlişkin Kriterler Faktörü" olarak adlandırılmıştır ve toplam varyansın \%18,13'ünü açıklamaktadır.

Üçüncü faktörü ortaya koyan 3 madde söz konusudur. Bunlar; “Etkileyicilerin Etkileyici Tanıtım veya Reklam Yapması Benim İçin Önemlidir”, “Etkileyicilerin Marka İle Uyumu Benim İçin Önemlidir", "Etkileyicilerin Profesyonel Çekim Yapması Benim İçin Önemlidir" ifadelerinin yer aldı̆̆ı maddelerdir. İfadelerden de anlaşılacağı gibi, burada doğrudan yapılan işin kalitesine etki eden, tanıtımı gerçekleştiren etkileyicinin sahip olduğu beceri, yetenek ve profesyonellik düzeyine odaklanan konular üzerine yoğunlaşılmaktadır. Bundan dolayı da bu faktör "Yetkinliğe İlişkin Kriterler Faktörü" olarak kavramsallaştırılmıştır ve toplam varyansın \%16,49'unu açıklamaktadır. 
Tablo 7: Etkileyicilerde Aranan Kriterler

\begin{tabular}{|c|c|c|c|c|c|}
\hline Etkileyicilerde Aranan Kriterler & A.O. & S.D. & 1 & 2 & 3 \\
\hline \multicolumn{6}{|l|}{ Tarza İlişkin Kriterler } \\
\hline $\begin{array}{l}\text { Etkileyicilerin Eğlenceli Olması Benim İçin } \\
\text { Önemlidir }\end{array}$ & 4,19 & 1,02 & ,778 & & \\
\hline $\begin{array}{l}\text { Etkileyicilerin Dürüst ve Samimi Olması Benim İçin } \\
\text { Önemlidir }\end{array}$ & 4,22 & 1,09 & ,738 & & \\
\hline $\begin{array}{l}\text { Etkileyicilerin Jest ve Mimikleri Benim İçin } \\
\text { Önemlidir }\end{array}$ & 4,11 & 1,00 & ,725 & & \\
\hline $\begin{array}{l}\text { Etkileyicilerin Çektiği Videoların İçeriği Benim İçin } \\
\text { Önemlidir }\end{array}$ & 4,00 & 1,08 & ,643 & & \\
\hline \multicolumn{6}{|l|}{ Fiziki Görünüşe İlişkin Kriterler } \\
\hline $\begin{array}{l}\text { Etkileyicilerin Fiziksel Olarak Çekici Olması Benim } \\
\text { İçin Önemlidir }\end{array}$ & 3,08 & 1,37 & & ,757 & \\
\hline $\begin{array}{l}\text { Etkileyicilerin Giydikleri Kıyafetler Benim İçin } \\
\text { Önemlidir }\end{array}$ & 3,36 & 1,27 & & ,698 & \\
\hline Etkileyicilerin Cinsiyeti Benim İçin Önemlidir & 2,10 & 1,27 & & 688 & \\
\hline \multicolumn{6}{|l|}{ Yetkinliğe İlişkin Kriterler } \\
\hline $\begin{array}{l}\text { Etkileyicilerin Etkileyici Tanıtım veya Reklam } \\
\text { Yapması Benim İçin Önemlidir }\end{array}$ & 3,10 & 1,25 & & & ,767 \\
\hline $\begin{array}{l}\text { Etkileyicilerin Marka ile Uyumu Benim İçin } \\
\text { Önemlidir }\end{array}$ & 2,94 & 1,30 & & & ,744 \\
\hline $\begin{array}{l}\text { Etkileyicilerin Profesyonel Çekim Yapması Benim } \\
\text { İçin Önemlidir }\end{array}$ & 3,42 & 1,32 & & & 468 \\
\hline Özdeğer (Eigenvalue) & & & 2,28 & 1,81 & 1,65 \\
\hline Açıklanan varyans & & & 22,87 & 18,13 & 16,49 \\
\hline Toplam açklanan varyans & \multicolumn{5}{|l|}{57,50} \\
\hline Cronbach's alpha & & & ,732 & 618 &, 503 \\
\hline Cronbach's alpha & \multicolumn{5}{|l|}{ 722 } \\
\hline KMO measure of sampling adequacy & \multicolumn{5}{|l|}{,757 } \\
\hline Bartlett's test of sphericity & \multicolumn{5}{|c|}{$X 2=897 s . d=45 \quad p<, 001$} \\
\hline
\end{tabular}

Etkileyicilerde aranan kriterlere ilişkin faktörler arasındaki ilişkinin yönünü ve düzeyini tespit etmek amacıyla gerçekleştirilen korelasyon analizi sonuçları Tablo 8 bağlamında değerlendirildiğinde, tarza ilişkin kriterler, fiziki görünüşe ilişkin kriterler ve yetkinliğe ilişkin kriterler arasında pozitif yönde, zayıf ve istatistiksel olarak anlamlı bir ilişki bulunduğu görülmektedir. Buradan yola çıkarak, etkileyicilerde aranan kriterler arasında zayıf da olsa bir etkileşim olduğunu, tarza, fiziki görünüşe ve yetkinliğe ilişkin kriterlerin tümünün etkileşimsel bir biçimde etkileyicilerde bulunmasının önemsendiğini ifade etmek mümkündür. 
Tablo 8: Etkileyicilerde Aranan Kriterlere İlişkin Faktörler Arasındaki İlişki

\begin{tabular}{|c|c|c|c|}
\hline & $\begin{array}{c}\text { Tarza İlişkin } \\
\text { Kriterler }\end{array}$ & $\begin{array}{c}\text { Fiziki Görünüşe } \\
\text { İlişkin Kriterler }\end{array}$ & $\begin{array}{c}\text { Yetkinliğe İlişkin } \\
\text { Kriterler }\end{array}$ \\
\hline Tarza İlişkin Kriterler & 1 &, $227^{*}$ &, $314^{*}$ \\
\hline Fiziki Görünüşe İlişkin Kriterler & & 1 &, $331^{*}$ \\
\hline Yetkinliğg İlişkin Kriterler & & & 1 \\
\hline
\end{tabular}

Not: ${ }^{*} p<, 001$

\subsubsection{Etkileyicilerde Aranan Kriterlerin Sosyo-Demografik Özellikler} Açısından Sergilediği Farklılaşma

Etkileyicilerde aranan kriterlerin sosyo-demografik özellikler açısından sergilediği farklılaşma durumu Tablo 9'da yer alan veriler referans alınarak incelendiğinde; Tarza ilişkin kriterlerin cinsiyet $(t=3,05 ; d f=467 ; p<, 005)$ ve yaş $(F=3,36 ; d f=2 ; p<$ ,05) yönünden anlamlı bir farklılaşma gösterirken; aylık ortalama harcama ( $F=$ 1,$72 ; d f=3 ; \quad p>$,05) açısından anlamlı bir farklılaşma ortaya koymadı̆̆ gözlenmektedir. Farklılaşma durumu çoklu karşılaştırma tabloları doğrultusunda değerlendirildiğinde, 19-20 yaş aralığında bulunanlarla 23-24 yaş aralığında yer alanlar $(, 238)$ arasında anlamlı bir farklılaşma gözlenmektedir. Buna göre, kadınlar (A.O.= 4,22) erkeklere (A.O.= 4,01) kıyasla; 19-20 yaş aralığında bulunanlar (A.O.= 4,21) 23-24 yaş aralığında yer alanlara (A.O.= 3,97) kıyasla etkileyicilerde tarza ilişkin kriterleri daha fazla aramaktadır.

Fiziki görünüşe ilişkin kriterlerin sadece aylık ortalama harcama $(F=3,90 ; d f=3 ; p<$ ,05) bakımından anlamlı bir farklılaşma sergilerken; cinsiyet $(t=-, 42 ; d f=469 ; p>, 05)$ ve yaş $(F=, 35 ; d f=2 ; p>, 05)$ yönünden anlamlı bir farklılaşma göstermediği anlaşılmaktadır. Mevcut farklılaşma durumuna çoklu karşılaştırma tabloları doğrultusunda bakıldığında, 1501 TL ve üzeri aylık ortalama harcaması bulunanlarla 501-1000 TL arası aylık ortalama harcama yapanlar (,327) ve 10011500 TL arası aylık ortalama harcama gerçekleştirenler (,395) arasında anlamlı bir farklılaşma olduğu fark edilmektedir. Bu minvalde, aylık ortalama harcaması 1501 ve üzeri olanlar (A.O.=3,11) 1001-1500 TL arası olanlara (A.O.=2,72) ve 501-1000 
TL arası olanlara (A.O.= 2,79) nazaran etkileyicilerde fiziki görünüşe ilişkin kriterlere daha fazla dikkat etmektedir.

Yetkinliğe ilişkin kriterlerin yalnızca cinsiyet $(t=3,53 ; d f=498 ; p<, 001)$ açısından anlamlı bir farklılaşma içerisine girerken; yaş $(F=, 08 ; d f=2 ; p>, 05)$ ve aylık ortalama harcama $(F=, 82 ; d f=3 ; p>, 05)$ bakımından böyle bir farklılaşmanın söz konusu olmadığı ortaya çıkmaktadır. Bu doğrultuda, kadınlar (A.O.= 3,29) erkeklere $(\mathrm{A} . \mathrm{O} .=3,00)$ göre etkileyicilerde yetkinliğe ilişkin kriterlere daha fazla hassasiyet göstermektedir.

Tablo 9: Etkileyicilerde Aranan Kriterlerin Sosyo-Demografik Özellikler Açısından Sergilediği Farklılaşma

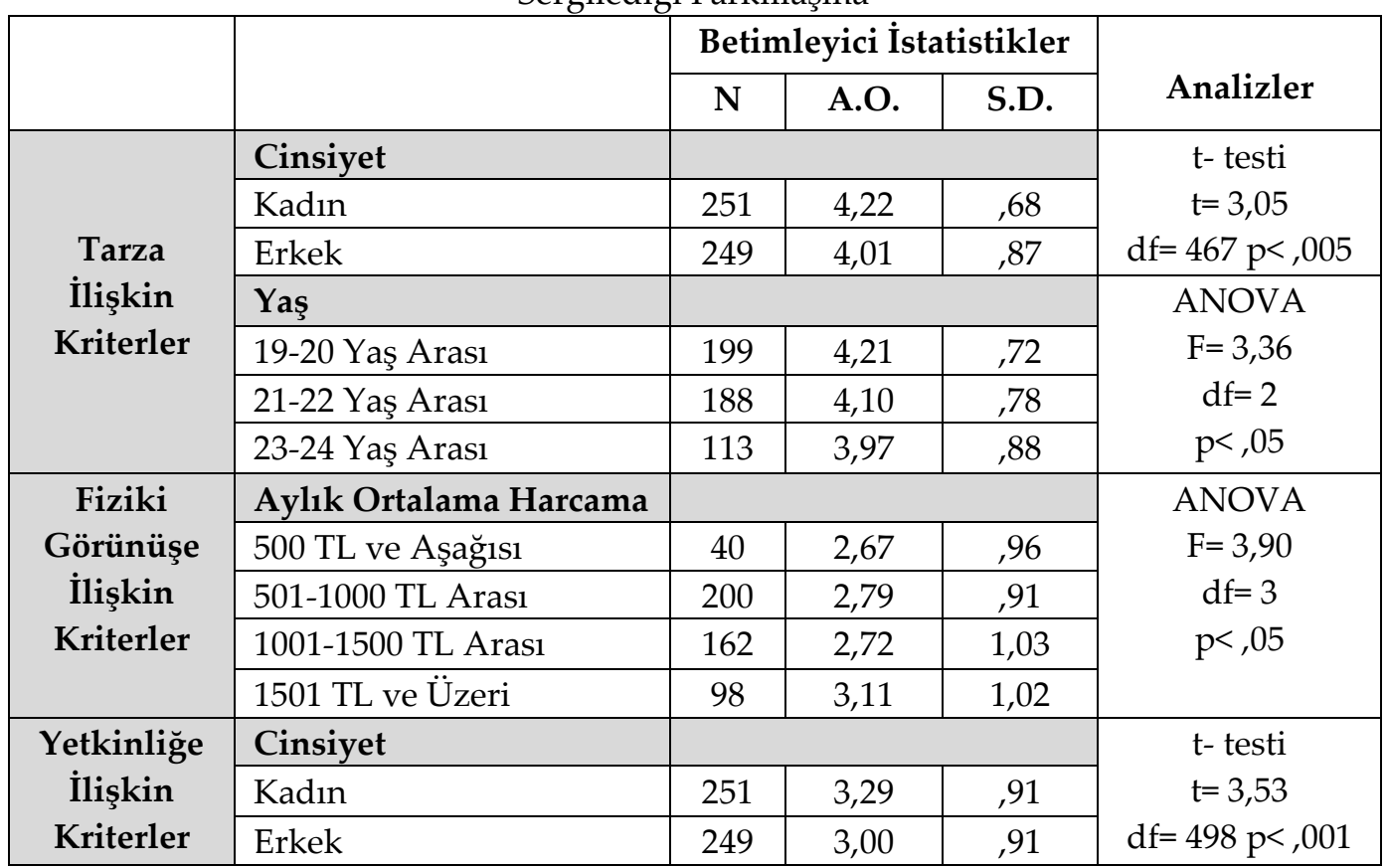

\subsection{Etkileyicilerin Takip Edilme Nedenlerine İlişkin Görüşler}

Bu başlık altında etkileyicilerin takip edilme nedenleri ve söz konusu nedenlerin sosyo-demografik özellikler bağlamında ortaya koyduğu farklılaşma betimlenmektedir.

\subsubsection{Etkileyicilerin Takip Edilme Nedenleri}

Sosyal medya ortamında etkileyicilerin takip edilme nedenlerini temsil eden temel değişkenlerin saptanması ve çalışmanın teorik altyapısında ortaya konulan 
görüşlerle ulaşılan sonuçların örtüşme düzeyini ortaya koymak amacıyla "kesinlikle katılmıyorum" ile "kesinlikle katılıyorum" arasında derecelendirilen 5’li Likert sıkalası kullanılarak düzenlenen 23 yargıya (item) verilen cevaplar doğrultusunda faktör analizi yapılmış, faktör analizi sonucunda çalışmanın teorik altyapısıyla da uyum gösteren 4 faktör grubunun ortaya çıkabildiği görülmüştür. Tablo 10' dan da anlaşılacağ üzere, bu faktörlerden birincisi “Bilgi Edinme Temelli Nedenler Faktörü", ikincisi "Hoşça Vakit Geçirme Temelli Nedenler Faktörü", üçüncüsü “Bireysel Tatmin Temelli Nedenler Faktörü” ve dördüncüsü “Etkileşim Temelli Nedenler Faktörü" olarak adlandırılmıştır. Faktör gruplarının sinıflandırılmasında ve değerlendirilmesinde varimax rotasyonlu tablo esas alınmıştır. Faktör analizine dahil edilen maddelerin güvenirlik katsayısı (Cronbach's $\alpha=, 893$ ) hayli yüksek bulunmuştur. Faktörlerin her birinin güvenirlik katsayısına bakıldığında ise, birinci faktör için $(, 822)$, ikinci faktör için $(, 786)$, üçüncü faktör için $(, 757)$ ve dördüncü faktör için $(, 629)$ gibi yine yüksek değerlere sahip olduğu görülmüştür.

Gerçekleştirilen faktör analizi sonucunda birinci faktörü açıklayan toplam 7 madde tespit edilmiştir. Bunlar; “Tecrübe Sahibi Olabiliyorum”, "Etkinliklerden Haberdar Oluyorum", "Ürün/Marka Tanitımlarından Haberdar Oluyorum", "Yeni Şeyler Öğrenebiliyorum", "Sıra Dışı Şeyler Görmek Hoşuma Gidiyor", “İlgimi Çeken Şeyleri Görmek Hoşuma Gidiyor” ve “Kendimi Eğitmek ve Zamana Uyum Sağlamak İstiyorum" ifadelerinin bulunduğu maddelerdir. Maddeler birlikte değerlendirildiğinde, tüketicilerin/takipçilerin herhangi bir ürüne/markaya, etkinliğe, yeniliğe ve farklılığa ilişkin bilgi ve tecrübe sahibi olması, yaşadığı birtakım öğrenme süreçlerinin ardından bilgi dağarcığını geliştirmesi üzerine odaklanan maddeler olduğu anlaşılmaktadır. Bu nedenle bu faktör "Bilgi Edinme Temelli Nedenler Faktörü" olarak isimlendirilmiştir ve toplam varyansın \%16,39' unu açılamaktadır.

Çalışmada ikinci faktörü açıklayan 5 madde saptanmıştır. Bunlar; "Özellikle Canım Sıkıldığında Zaman Geçirmemi Sağlıyor”, “Bazen Yapacak Daha İyi Bir 
Şeyim Olmayabiliyor”, “Zaman Geçirmek İstediğimde Bana Bir Şeyler Katıyor” ve “Böylece Günlük Hayatın Stresinden Uzaklaşabiliyorum” ile ilgili maddelerdir. Bahse konu olan maddeler, tüketicilerin/takipçilerin rasyonel bir tutum takınarak alacakları kararlara zemin teşkil edecek bilgileri edinmekten ziyade, gündelik yaşamın sıkıntılarından kurtulmak, boş zamanı değerlendirmek ve pozitif ruh haline bürünmek gibi hoşça vakit geçirme temelli davranışlar üzerine yoğunlaşmaktadır. Bundan ötürü de bu faktör "Hoşça Vakit Geçirme Temelli Nedenler Faktörü" olarak adlandırılmıştır ve toplam varyansın \%15,07'sini açıklamaktadır.

Üçüncü faktörü ortaya koyan 5 madde söz konusudur. Bunlar; "Hoş ve Havalı", "Mutlu Oluyorum", "Eğlenceli Buluyorum", "Yapılması Gereken Bir Şey Olduğunu Düşünüyorum" ve "Beni Rahatlatıyor" ifadelerinin yer aldığ1 maddelerdir. İfadelerden de anlaşılacağı gibi bu maddeler, tüketiciler/takipçiler için bireysel hazzı ön plana çıkarmakta, bireyin eğlenme, mutlu olma ve rahatlama gibi tatmin yaşamasına dönük vurgularda bulunmaktadır. Buradan hareketle bu faktör "Bireysel Tatmin Temelli Nedenler Faktörü" olarak kavramsallaştırılmıştır ve toplam varyansın \%13,11'ini açıklamaktadır.

Dördüncü faktör 4 madde ile ortaya konulmaktadır. Bunlar; “Bazen Konuşacak ya da Birlikte Bir Şeyler Yapacak Birilerini Bulamıyorum”, "Kendimi Daha Az Yalnız Hissetmemi Sağlıyor", "Ben de Etkileyici Olmak İstiyorum” ve "Karşı Cins Etkileyiciler Beni Etkiliyor" yargılarını barındıran maddelerdir. Söz konusu maddeler, tüketicilerin/takipçilerin yalnızlık hissinden yola çıkarak etkileyiciler ile gerçekleşen iletişimi ve etkileşimi odağına alan maddeler olmaları hasebiyle, bu faktör "Etkileşim Temelli Nedenler Faktörü" olarak ifadeleştirilmiştir ve toplam varyansın \%11,02'sini açıklamaktadır. 
Dijital Çağın Bir Pazarlama ve Marka İletişim Aracı Olarak Etkileyiciler: Kanaatler, ...

Tablo 10: Etkileyicilerin Takip Edilme Nedenleri

\begin{tabular}{|c|c|c|c|c|c|c|}
\hline Etkileyicilerin Takip Edilme Nedenleri & A.O. & S.D. & 1 & 2 & 3 & 4 \\
\hline \multicolumn{7}{|l|}{ Bilgi Edinme Temelli Nedenler } \\
\hline Tecrübe Sahibi Olabiliyorum & 3,95 & 1,00 & ,763 & & & \\
\hline Etkinliklerden Haberdar Oluyorum & 3,79 & 1,02 & ,732 & & & \\
\hline $\begin{array}{l}\text { Ürün/Marka Tanıtımlarından Haberdar } \\
\text { Oluyorum }\end{array}$ & 3,58 & 1,16 & 646 & & & \\
\hline Yeni Şeyler Öğrenebiliyorum & 3,88 & 1,01 & ,643 & & & \\
\hline Sıra Dışı Şeyler Görmek Hoşuma Gidiyor & 4,12 &, 94 & 607 & & & \\
\hline $\begin{array}{l}\text { İlgimi Çeken Şeyleri Görmek Hoşuma } \\
\text { Gidiyor }\end{array}$ & 4,15 & ,91 & ,594 & & & \\
\hline $\begin{array}{l}\text { Kendimi Eğitmek ve Zamana Uyum } \\
\text { Sağlamak İstiyorum }\end{array}$ & 3,30 & 1,21 & 454 & & & \\
\hline \multicolumn{7}{|l|}{ Hoşça Vakit Geçirme Temelli Nedenler } \\
\hline $\begin{array}{l}\text { Özellikle Canım Sikıldığında Zaman } \\
\text { Geçirmemi Sağlıyor }\end{array}$ & 3,95 & 1,07 & & ,752 & & \\
\hline $\begin{array}{l}\text { Bazen Yapacak Daha İyi Bir Şeyim } \\
\text { Olmayabiliyor }\end{array}$ & 3,42 & 1,21 & & 625 & & \\
\hline $\begin{array}{l}\text { Zaman Geçirmek İstediğimde Bana Bir } \\
\text { Şeyler Katıyor }\end{array}$ & 3,69 & 1,07 & & 600 & & \\
\hline $\begin{array}{l}\text { Böylece Günlük Hayatın Stresinden } \\
\text { Uzaklaşabiliyorum }\end{array}$ & 3,48 & 1,18 & & ,561 & & \\
\hline $\begin{array}{l}\text { Negatif Ruh Halimi Pozitif Ruh Haline } \\
\text { Dönüştürüyor }\end{array}$ & 3,46 & 1,13 & & 497 & & \\
\hline \multicolumn{7}{|l|}{ Bireysel Tatmin Temelli Nedenler } \\
\hline Hoş ve Havalı & 3,69 & 1,09 & & & ,737 & \\
\hline Mutlu Oluyorum & 3,71 & 1,08 & & & 678 & \\
\hline Eğlenceli Buluyorum & 4,20 &, 89 & & & ,640 & \\
\hline $\begin{array}{l}\text { Yapılması Gereken Bir Şey Olduğunu } \\
\text { Düşünüyorum }\end{array}$ & 3,05 & 1,17 & & & ,542 & \\
\hline Beni Rahatlatıyor & 3,20 & 1,17 & & & 454 & \\
\hline \multicolumn{7}{|l|}{ Etkileşim Temelli Nedenler } \\
\hline $\begin{array}{l}\text { Bazen Konuşacak ya da Birlikte Bir } \\
\text { Şeyler Yapacak Birilerini Bulamıyorum }\end{array}$ & 2,65 & 1,37 & & & & ,762 \\
\hline $\begin{array}{l}\text { Kendimi Daha Az Yalnız Hissetmemi } \\
\text { Sağllyor }\end{array}$ & 2,64 & 1,28 & & & & 741 \\
\hline Ben de Etkileyici Olmak İstiyorum & 2,46 & 1,43 & & & &, 584 \\
\hline Karşı Cins Etkileyiciler Beni Etkiliyor & 2,51 & 1,29 & & & & ,423 \\
\hline Özdeğer (Eigenvalue) & & & 3,44 & 3,16 & 2,75 & 2,31 \\
\hline Açıklanan varyans & & & 16,39 & 15,07 & 13,11 & 11,02 \\
\hline Toplam açılanan varyans & \multicolumn{6}{|l|}{55,61} \\
\hline Cronbach's alpha & & & 822 & ,786 & ,757 &, 629 \\
\hline Cronbach's alpha & \multicolumn{6}{|l|}{,893 } \\
\hline KMO measure of sampling adequacy & \multicolumn{6}{|l|}{903} \\
\hline Bartlett's test of sphericity & \multicolumn{6}{|c|}{$X 2=3471$ s.d $=210 \quad p<, 001$} \\
\hline
\end{tabular}

Etkileyicilerin takip edilme nedenlerine ilişkin faktörler arasındaki ilişkinin yönünü ve şiddetini ortaya koymak üzere gerçekleştirilen korelasyon analizinden 
elde edilen sonuçlar Tablo 11 referans alınarak incelendiğinde, hoşça vakit geçirme temelli nedenler ile bireysel tatmin temelli nedenler ve bilgi edinme temelli nedenler arasında pozitif yönde, güçlü ve istatistiksel olarak anlamlı bir ilişki varken; bilgi edinme temelli nedenlerle bireysel tatmin temelli nedenler ve hoşça vakit geçirme temelli nedenlerle etkileşim temelli nedenler arasında pozitif yönde, orta düzeyde ve istatistiksel olarak anlamlı bir ilişki bulunmakta; buna karşın etkileşim temelli nedenlerle bilgi edinme temelli nedenler ve bireysel tatmin temelli nedenler arasında pozitif yönde, zayıf ve istatistiksel olarak anlamlı bir ilişki söz konusu olmaktadır. Bu verilerden yola çıkarak, etkileyicilerin takip edilme nedenleri arasında farklı düzeylerde de olsa bir etkileşim olduğunu, bu bağlamda da, bilgi edinme, hoşça vakit geçirme, bireysel tatmin ve etkileşim temelli nedenlerin hepsinin etkileşimsel biçimde biraradalığ etkileyicilerin takip edildiğini belirtmek mümkündür.

Tablo 11: Etkileyicilerin Takip Edilme Nedenlerine İlişkin Faktörler Arasındaki İlişki

\begin{tabular}{|c|c|c|c|c|}
\hline & $\begin{array}{c}\text { Bilgi } \\
\text { Edinme } \\
\text { Temelli } \\
\text { Nedenler }\end{array}$ & $\begin{array}{c}\text { Hoşça Vakit } \\
\text { Geçirme } \\
\text { Temelli } \\
\text { Nedenler }\end{array}$ & $\begin{array}{c}\text { Bireysel Tatmin } \\
\text { Temelli } \\
\text { Nedenler }\end{array}$ & $\begin{array}{c}\text { Etkileşim } \\
\text { Temelli } \\
\text { Nedenler }\end{array}$ \\
\hline $\begin{array}{c}\text { Bilgi Edinme Temelli } \\
\text { Nedenler }\end{array}$ & 1 &, $609^{*}$ &, $579^{*}$ &, $359^{*}$ \\
\hline $\begin{array}{c}\text { Hoşça Vakit Geçirme } \\
\text { Temelli Nedenler }\end{array}$ & 1 & $1,637^{*}$ &, $321^{*}$ \\
\hline $\begin{array}{c}\text { Bireysel Tatmin Temelli } \\
\text { Nedenler }\end{array}$ & & & & 1 \\
\hline Etkileşim Temelli Nedenler & & & & \\
\hline
\end{tabular}

Not: ${ }^{*} p<, 001$

\subsubsection{Etkileyicilerin Takip Edilme Nedenlerinin Sosyo-Demografik Özellikler}

\section{Açısından Sergilediği Farklılaşma}

Etkileyicilerin takip edilme nedenlerinin sosyo-demografik özellikler açısından sergilemiş olduğu farklılaşma değerlendirildiğinde;

Bilgi edinme temelli nedenlerin sadece cinsiyet $(t=2,89 ; d f=498 ; p<, 005)$ açısından anlamlı bir farklılaşma içeresine girdiği, bunun dışında yaş $(F=1,66 ; d f=2 ; p>, 05)$ ve aylık ortalama harcama $(F=, 75 ; d f=3 ; p>, 05)$ açısından anlamlı herhangi bir farklılaşmanın olmadığı gözlenmektedir. Tablo 12'den de anlaşılacağı üzere, 
kadınlar (A.O.=3,89) erkeklere (A.O.=3,71) nazaran etkileyicileri bilgi edinme temelli nedenlerle daha çok takip etmektedir.

Hoşça vakit geçirme temelli nedenlerin cinsiyet $(t=, 07 ; d f=498 ; p>, 05)$, yaş $(F=1,09$; $d f=2 ; p>, 05)$ ve aylık ortalama harcama $(F=, 60 ; d f=3 ; p>, 05)$ bakımından sergilemiş olduğu herhangi bir farklılaşma bulunmamaktadır.

Bireysel tatmin temelli nedenlerin cinsiyet $(t=, 26 ; d f=498 ; p>, 05)$, yaş $(F=, 63 ; d f=2$; $p>, 05)$ ve aylık ortalama harcama $(F=2,02 ; d f=3 ; p>, 05)$ yönünden gösterdiği herhangi bir farklılaşma söz konusu değildir.

Etkileşim temelli nedenlerin cinsiyet $(t=-, 24 ; d f=498 ; p>, 05)$, yaş $(F=1,61 ; d f=2 ; p>$ ,05) ve aylık ortalama harcama $(F=, 69 ; d f=3 ; p>, 05)$ bağlamında ortaya koymuş olduğu herhangi bir farklılaşmaya rastlanamamaktadır.

Tablo 12: Etkileyicilerin Takip Edilme Nedenlerinin Cinsiyet Açısından Sergilediği Farklılaşma

\begin{tabular}{|c|c|c|c|c|c|}
\hline \multirow{5}{*}{$\begin{array}{c}\text { Bilgi } \\
\text { Edinme } \\
\text { Temelli } \\
\text { Nedenler }\end{array}$} & & \multicolumn{3}{|c|}{ Betimleyici İstatistikler } & \multirow[b]{2}{*}{ Analiz } \\
\hline & & $\mathbf{N}$ & A.O. & S.D. & \\
\hline & Cinsiyet & & & & \multirow{3}{*}{$\begin{array}{c}\mathrm{t}-\text { testi } \\
\mathrm{t}=2,89 \\
\mathrm{df}=498 \mathrm{p}<, 005\end{array}$} \\
\hline & Kadın & 251 & 3,89 & 71 & \\
\hline & Erkek & 249 & 3,71 & ,72 & \\
\hline
\end{tabular}

\section{Sonuç ve Değerlendirme}

Bilgi toplumuna geçiş süreciyle ortaya çıkan dijitalleşme ve beraberinde getirdiği köklü nitelikteki değişim ve dönüşüm, hem toplumları hem de toplumsal yapı içerisinde yer alan unsurlar olan bireyleri ve kurumsal yapıları yeni oluşumlarla karşı karşıya getirmiştir. Dijital çağın doğasının bir sonucu olan söz konusu yenilikler, önceki dönemlerin yapı ve alışkanlıklarının çok ötesinde, kimi zaman onları ters yüz edebilecek düzeyde ve oldukça hızlı yayılan bir karakter taşımaktadır. Kendine özgü bir düzeni ve işleyişi bulunan bu yeni çağa ayak uydurabilmek için bütüncül bir yaklaşım sergilenmesi, birbiriyle girift ilişkiler içerisinde olan gelişmelerin özünün iyi kavranması gerekmektedir. İstenen faydayı elde edebilmek ancak bu şekilde mümkündür. 
Dijital çağın kurumsal yapılar için getirmiş olduğu yeniliklerden birisi ise, pazarlama ve marka iletişimi alanında ortaya çıkan etkileyiciler ve etkileyici kişi pazarlamasıdır. Tüketicilerin/takipçilerin ilgilendiği ürüne ilişkin görüşlerini belirterek onların satın olma davranışlarına yön veren kişilerin varlığı kurumsal yapılar tarafından keşfedilmekte geç kalınmamıştır. Rasyonel varlıklar olan kuruluşlar, ilgili kişilerden pazarlama ve marka iletişimi süreçlerinde yararlanmaya başlamışlar ve bunun sonucunda da işlevsel kullanılabilecek yeni bir enstrüman olan etkileyiciler ortaya çıkmıştır. Esasında hem kurumlar hem de tüketici konumundaki bireyler için önemli yarar potansiyelleri taşıyan etkileyicileri çok farklı boyutlarıyla ele almak mümkündür. Bu çalışmada, etkileyicilere tüketiciler/takipçiler açısından yaklaşılmış, onlara ilişkin genel kanaatler, aranılan kriterler ve takip nedenleri, Süleyman Demirel Üniversitesi öğrencileri üzerinde gerçekleştirilen alan araştırmasından elde edilen bulgular özelinde aşağıdaki şekilde özetlenmiştir:

Katılımcıların yarıdan fazlası üçün üzerinde etkileyici takip etmekte; etkileyicilerin sosyal medya ortamları içerisinde yoğunlukla ilk olarak takip edilmeye başlandığı yer Instagram olarak karşımıza çıkmaktadır. Kadınlarda bariz bir biçimde görülen bu durumdan farklı olarak erkekler Instagram'ın yanı sıra diğer sosyal medya ortamlarından da etkileyici takibine başlamaktadır. Instagram, aylık ortalama harama itibariyle tüm gruplarda etkileyicilerin ilk olarak takip edilmeye başlandığı sosyal medya ortamı olarak çok ön plana çıkmakla beraber; harcama miktarında yaşanan artışla Instagram, Twitter ve diğer sosyal medya ortamlarının bu özelliğinde bir artış, Facebook'ta ise bir düşüş meydana gelmektedir.

Etkileyicilerin yerli ya da yabancı olması çok fazla önemsenmemektedir. Bu kişilerin en fazla sanat-eğlence, kıyafet, kişisel bakım-kozmetik ve truzim-seyahat alanlarındaki tanıtımları tesirli olurken; en az anne-çocuk ve sağlık alanlarındaki tanıtımları etki uyandırmaktadır. Kıyafet, kişisel bakım-kozmetik, aksesuar, turizm-seyahat ve anne-çocuk alanında kadınlar etkileyicilerin tanıtımlarının 
tesirinde daha fazla kalırken; elektronik aletler, spor malzemeleri ve yukarıda bahsi geçen kategoriler dışında kalan diğer alanlarda erkekler söz konusu etkiyi daha fazla hissetmektedir. Ayrıca, yaş ilerledikçe etkileyicilerin kıyafet ve aksesuar alanındaki tanıtımlarının tesiri azalmakta; aylık ortalama harcaması 5011000 TL arasinda bulunanlar ile 1001-1500 TL arasinda bulunanlar, 1501 TL ve üzerinde olanlar ile 500 TL ve aşağısında olanlara kıyasla etkileyicilerin sanateğlence alanındaki tanıtımlarının tesiri altında daha fazla kalmaktadır.

Etkileyicilerin yerinde olmak konusunda yarı yarıya bir görüş ayrıllı̆̆1 bulunmakta, geneli kapsayan bir isteklilik durumu söz konusu olmamaktadır. Yaş, bu noktada belirleyici rol üstlenmekte, yaş ilerledikçe etkileyicilerin yerinde olmayı isteme durumunda bir azalma meydana gelmektedir. Bununla birlikte, bir markayı satın almadan önce etkileyicilerin tanıtım videolarının izlenmesinde/izlenmemesinde daha çok ilgili ürün belirleyici olmakta ve kadınlar bu süreçte etkileyicilerin tanıtım videolarını daha fazla izlemektedir. Yaygın kanaat etkileyicilerin marka tanıtımında veya pazarlamasında etkisinin olduğu yönündedir ve bu kanaati kadınlar daha fazla taşımaktadır. Ayrıca, etkileyicilerin tanıtımları satın alma davranışı üzerinde bir etkiye sahiptir ve etkileyicilerin tanıtımlarının kadınların satın alma davranışları üzerindeki tesiri daha fazladır. Sosyal medya ortamında tüketicilerin/takipçilerin etkileyicilerde aradıkları kriterler, tarza ilişkin kriterler, fiziki görünüşe ilişkin kriterler ve yetkinliğe ilişkin kriterler olmak üzere üç başlık altında toplanmaktadır. Etkileyicilerde aranan kriterler arasında zayıf da olsa bir etkileşim vardır. Bunun yanı sıra, kadınlar erkeklere kıyasla, 19-20 yaş aralığında bulunanlar 23-24 yaş aralığında yer alanlara kıyasla etkileyicilerde tarza ilişkin kriterleri daha fazla ararken; aylık ortalama harcaması 1501 TL ve üzeri olanlar 1001-1500 TL arası olanlara ve 501-1000 TL arası olanlara nazaran etkileyicilerde fiziki görünüşe ilişkin kriterlere daha fazla dikkat etmekte ve son olarak da kadınlar erkeklere göre etkileyicilerde yetkinliğe ilişkin kriterlere daha fazla hassasiyet göstermektedir. 
Sosyal medya ortamında etkileyicilerin takip edilme nedenleri, bilgi edinme temelli nedenler, hoşça vakit geçirme temelli nedenler, bireysel tatmin temelli nedenler ve etkileşim temelli nedenler olmak üzere 4 boyutta karşımıza çıkmaktadır. Etkileyicilerin takip edilme nedenleri arasında farklı düzeylerde de olsa bir etkileşim vardır. Ayrıca, kadınlar erkeklere nazaran etkileyicileri bilgi edinme temelli nedenlerle daha çok takip etmektedir.

Araştırma bulguları doğrultusunda, sosyal medya ortamlarının etkileşimli doğasıyla ortaya çıkan etkileyiciler, dijital çağın bir pazarlama ve marka iletişin aracı olarak önemli bir işlev üstlenmektedir. Tüketicilerin kanaatleri üzerinde etki potansiyeli bulunan bu kişilerin kurumsal yapılar tarafından görmezden gelinmesi pek mümkün gözükmemekle birlikte, rasyonel bir davranış tarzı da olmayacaktır. Ancak kurumlar, pazarlama ve marka iletişim süreçlerine bu kişileri dahil ederken, tüketici profillerini, ürünlerini, bu kişilerde ne tür kriterler arayacaklarını en ince ayrıntısına kadar hesap etmeli, takınacakları tavırları ve atacakları adımları bu minvalde değerlendirmelidir.

\section{KAYNAKLAR}

Akdevelioğlu D (2013) Who are the Influentials? The Relationship Between Opinion Leadership and New Product Adoption, Yüksek Lisans Tezi, BÜ Sos. Bil. Enst., Ankara.

Aktaş A (2018) Nüfuz Pazarlamasında (Influencer Marketing) Kullanılan Mesaj Stratejilerine Yönelik Bir İçerik Analizi, Yüksek Lisans Tezi, BAU Sos. Bil. Enst., İstanbul.

Alikılıç İ ve Özkan B (2018) Bir Sosyal Medya Pazarlama Trendi, Hatırlı Pazarlama ve Etkileyiciler: Instagram Fenomenleri Üzerine Bir Araştırma, Uluslararası Sosyal Bilimler Dergisi, 1(2), 43-57.

Arklan, Ü ve Kartal, N Z (2018) Y Kuşağının Tüketici Olarak YouTube Kullanımı: Kullanım Amaçları, Kullanım Düzeyleri ve Takip Edilen İçerikler Üzerine Bir Araştırma, Gümüşhane Üniversitesi İletişim Fakültesi Elektronik Dergisi, 6(2), 929-965. 
Aslan A ve Ünlü D G (2016) Instagram Fenomenleri ve Reklam İlişkisi: Instagram Fenomenlerinin Gözünden Bir Değerlendirme, Maltepe Üniversitesi İletişim Fakültesi Dergisi, 3(2), 41-65.

Avcılar M Y, Demirgüneş B K ve Açar M F (2018) Instagram Reklamlarında Ürün Destekçisi Olarak Sosyal Medya Fenomeni Kullanımının Reklama Yönelik Tutum ve E-WOM Niyetine Etkilerinin İncelenmesi, Pazarlama ve Pazarlama Araştırmaları Dergisi, 21, 1-27.

Aydemir Ö F (2017) Sosyal Medya Fenomenlerinin Tüketicilerin Ürün Reklamlarını Algılaması Üzerine Etkisi, Yüksel Lisans Tezi, KOÜ Sos. Bil. Enst., Kocaeli.

Ayhan A (2012) Yedi Adımda Markalaşma, Sistem Yayıncılık, İstanbul.

Başer A (2014) Sosyal Medya Kullanıcılarının Kişilik Özellikleri, Kullanım ve Motivasyonlarının Sosyal Medya Reklamlarına Yönelik Genel Tutumları Üzerindeki Rolü: Facebook Üzerine Bir Uygulama, Doktora Tezi, MÜ Sos. Bil. Enst., İstanbul.

Bayraktar Ö (2017) Dijital İşletme Bilimi, Selis Kitaplar, İstanbul.

Bor H M ve Erten A (2019) Dijital Çağın Mesleği: Nasıl Influencer Olunur?, Hürriyet Kitap, İstanbul.

Bóveda-Lambie, A M ve Hair N (2012) Advertising Versus Invertising: The Influence of Social Media B2C Efforts On Consumer Attitudes and Brand Relationships, Online consumer behaviour: Theory and research in social media, advertising, and e-tail, Angeline G. Close (eds), Routledge, New York, 209-236.

Brown D ve Hayes N (2008) Influencer Marketing: Who Really Influences Your Customers?, Butterworth-Heinemann, Oxford.

Büyükkuşoğlu S (2017) Influencers on Instagram Turkey: Performing The 'Iconic Mother' And The 'Iconic Woman', Yüksek Lisans Tezi, SÜ Sos. Bil. Enst., İstanbul.

Cambridge Dictionary (2019) Influencer, https://dictionary.cambridge.org/tr/s\%C3\%B6zl\%C3\%BCk/ingilizce/influencer, erişim tarihi: 27.01.2019.

Chatzigeorgiou C (2017) Modelling The Impact of Social Media Influencers on Behavioural Intentions of Millennials: The Case of Tourism in Rural Areas in Greece, Journal of Tourism, Heritage and Services Marketing, 3(2), 25-29. 
Coşkun C (2018) Marka, Ajans ve Youtuber Üçgeninde Nüfuz Pazarlamasının Belirleyici Unsurları, Yüksek Lisans Tezi, BAU Sos. Bil. Enst., İstanbul

Çelikkaya G (2017) Başarılı Bir Influencer Marketing Kampanyası İçin 8 Temel Öneri, https://www.guvencelikkaya.com/?p=467, erişim tarihi: 29.01.2019.

De Veirman M, Cauberghe V ve Hudders L (2017) Marketing Through Instagram Influencers: The Impact of Number of Followers and Product Divergence On Brand Attitude, International Journal of Advertising, 36(5), 798-828.

Deneçli S (2015) Markaların Sosyal Medya Yönetimi, Kriter Yayınevi, İstanbul.

Ducoffe R H (1995) How Consumers Assess The Value of Advertising, Journal of Current Issues and Research in Advertising, 17(1), 1-18.

English Oxford Living Dictionaries (2019) Influencer, https://en.oxforddictionaries.com/definition/influencer, erişim tarihi: 27.01.2019.

Erdil T S ve Uzun Y (2009) Marka Olmak, Beta Basım Yayım Dağıtım, İstanbul.

Evans N J, Phua J, Lim J ve Jun H (2017) Disclosing Instagram Influencer Advertising: The Effects of Disclosure Language on Advertising Recognition, Attitudes, and Behavioral Intent, Journal of Interactive Advertising, 17(2), 138-149.

Fleck N, Korchia M ve Le Roy I (2012) Celebrities in Advertising: Looking for Congruence or Likability?, Psychology and Marketing, 29(9), 651-662.

Gerçek Gündem (2018) Influencer ne demek?, https://www.gercekgundem.com/bilim-teknoloji/17374/influencer-ne-demek, erişim tarihi: 24.01.2019.

Görgülü G ve Farajova T (2017) Sosyal Medya Fenomenleri, Takipçilerinin Satın Alma Tercihlerine Ne Kadar Etki Ediyor? İçerikle Pazarlama Konferansı, 11 Mayıs 2017, İstanbul.

Hennessy B (2018) Influencer: Building Your Personal Brand in the Age of Social Media, Citadel Press, New York.

Kim, H C ve Jeong, J Y (2016) Effect Of Celebrity Endorsement in Marketing of Musicals: Poster Versus Social Networking Site, Social Behavior and Personality, $44(8), 1243-1254$. 
Dijital Çağın Bir Pazarlama ve Marka İletişim Aracı Olarak Etkileyiciler: Kanaatler, ...

Kiss C ve Bichler M (2008) Identification of Influencers - Measuring Influence in Customer Networks, Decision Support Systems, 46(1), 233-253.

Koçyiğit M (2015) Sosyal Ağ Pazarlaması: Marka Bağlılı̆̆ı Oluşturmada Yeni Bir Pazarlama Stratejisi, Eğitim Yayınevi, Konya.

Kolcuoğlu R A (2018) Instagram'da Nüfuz Pazarlaması (Influencer Marketing) ve Doğal Reklamlar Üzerine Betimleyici Bir Araştırma, Yüksek Lisans Tezi, AÜ Sos. Bil. Enst., Antalya.

Kotler P ve Pfoertsch W (2010) B2B Marka Yönetimi: Firmadan Firmaya Satışta (B2B) Marka Nasıl Yaratılır?, Nezih Orhon (çev), MediaCat Kitapları, İstanbul.

Lincoln J (2016) Digital Influencer: A Guide to Achieving Influencer Status Online, CreateSpace Independent Publishing Platform.

Liu S, Jiang C, Lin Z, Ding Y, Duan R ve Xu Z (2015) Identifying Effective Influencers Based on Trust for Electronic Word-of-Mouth Marketing: A DomainAware Approach, Information Sciences, 306, 34-52.

Maden D (2018) The Role of Digital Influencers in the Diffusion of New Products, Akdeniz İletişim Dergisi, 30, 119-141.

Matsumura N, Yamamoto H ve Tomozawa D (2008) Finding Influencers and Consumer Insights in the Blogosphere, 2nd International Conference on Weblogs and Social Media, ICWSM 2008, 2008 Mar 30-Apr 2, 76-83.

McAlexander, J H, Schouten, J W ve Koenig, H F (2002) Building Brand Community, Journal of Marketing, 66(1), 38-54.

Mert Y L (2018) Dijital Pazarlama Ekseninde Influencer Marketing Uygulamaları, Gümüşhane Üniversitesi İletişim Fakültesi Elektronik Dergisi, 6(2), 1299-1328.

Nisbet M C ve Kotcher John E (2009) A Two-Step Flow of Influence? OpinionLeader Campaigns on Climate Change, Science Communication, 30(3), 328-354.

Özbek M B (2018) The Affect of Phenomenon Marketing on Purchasing Decisions, Yüksek Lisans Tezi, BAU Sos. Bil. Enst., İstanbul.

Öztürk E ve Şener G (2018) Modada Nüfuz Pazarlaması: Mikro Instabloggerların Ürün Yerleştirme Uygulamaları, Selçuk İletişim, 11(1), 382-412. 
Özutku F, Küçükyılmaz M M, Çopur H, İlter K, Sığın İ ve Arı Y (2014) Sosyal Medyanın ABC'si, Alfa Basım Yayım Dağıtım, İstanbul.

Sabuncuoğlu A ve Gülay G (2014) Sosyal Medyadaki Yeni Kanaat Önderlerinin Birer Reklam Aracı Olarak Kullanımı: Twitter Fenomenleri Üzerine Bir Araştırma, İletişim Kuram ve Araştırma Dergisi, 38, 1-24.

Sammis K, Lincoln C, Pomponi S, Ng J, Rodriguez E G ve Zhou J (2015) Influencer Marketing for Dummies: A Wiley Brand, John Wiley and Sons, New Jersey.

Shimp T A (2007) Advertising, Promotion and Other Aspects of Integrated Marketing Communications, Thomsos South-Western, Ohio.

Sözen D (2016) Tüketicilerin Sosyal Medya Pazarlama Aktivitelerine Katılımları, Etkileyicileri ve Belirleyicileri Üzerine Bir Araştırma, Yüksek Lisans Tezi, AİBÜ Sos. Bil. Enst., Bolu.

Tahtalı M Ç (2018) Sosyal Etki Pazarlaması Bağlamında Youtuberların İletişim Stratejileri Üzerine Niteliksel Bir Araştırma, Yüksek Lisans Tezi, AÜ Sos. Bil. Enst., Ankara.

Trepte S ve Scherer H (2010) Opinion Leaders: Do They Know More Than Others About Their Area of Interest? Communications, 35(2), 119-140.

Ulusal Tez Merkezi (2019) Etkileyiciler ve Etkileyici Kişi Pazarlaması, https://tez.yok.gov.tr/UlusalTezMerkezi/tezSorguSonucYeni.jsp, erişim tarihi: 1.02.2019.

Uyar A (2014) İnovatif Ürünlerin Yayılımında Fikir Liderlerinin Rolü: Tüketiciler Üzerine Bir Araştırma, Doktora Tezi, AKÜ Sos. Bil. Enst., Afyonkarahisar.

Uzunoğlu E ve Kip S M (2014) Brand Communication Through Digital Influencers: Leveraging Blogger Engagement, International Journal of Information Management, 34, 592-602.

Varnalı K (2013) Dijital Tutulma: Pazarlama İletişimi ve İnsan, MediaCat Kitapları, İstanbul.

Watts D J ve Dodds, P S (2007) Influentials, Networks, and Public Opinion Formation, Journal of Consumer Research 34(4), 441-458. 
Dijital Çağın Bir Pazarlama ve Marka İletişim Aracı Olarak Etkileyiciler: Kanaatler, ...

Wiedmann K P, Hennigs N ve Langner S (2010) Spreading the Word of Fashion: Identifying Social Influencers in Fashion Marketing, Journal of Global Fashion Marketing, 1(3), 142-153.

Yaman E S (2018) Ürün Yerleştirmede Yeni Bir Alan: Influencer Marketing Sosyal Medyada Influencer Annelerin Takipçileri Tarafından Değerlendirilmesine Yönelik Bir Araştırma 2. Uluslararası İletişimde Yeni Yönelimler Konferansı Eğlence ve Ürün Yerleştirme, 3-4 Mayıs 2018, 268-279.

Yaylagül Ş (2017) Sosyal Medya Fenomenlerine Bağlanmışlığın Belirlenmesi: Yükseköğretim Öğrencileri Üzerine Bir Uygulama, Adnan Menderes Üniversitesi Sosyal Bilimler Enstitüsü Dergisi, 4(3), 219-235.

Zhang Y, Li X ve Wang T W (2013) Identifying Influencers in Online Social Networks: The Role of Tie Strength, International Journal of Intelligent Information Technologies, 9(1), 1-20. 